Illinois State University

ISU ReD: Research and eData

Theses and Dissertations

9-30-2013

\title{
An Uncommon Splice: Seeking Mutations in the Life-Writing and Short Fiction of Mary Butts and Djuna Barnes
}

Susan George

Illinois State University, smgeorge27@gmail.com

Follow this and additional works at: https://ir.library.illinoisstate.edu/etd

Part of the English Language and Literature Commons, Feminist, Gender, and Sexuality Studies Commons, and the Modern Literature Commons

\section{Recommended Citation}

George, Susan, "An Uncommon Splice: Seeking Mutations in the Life-Writing and Short Fiction of Mary Butts and Djuna Barnes" (2013). Theses and Dissertations. 282.

https://ir.library.illinoisstate.edu/etd/282

This Thesis is brought to you for free and open access by ISU ReD: Research and eData. It has been accepted for inclusion in Theses and Dissertations by an authorized administrator of ISU ReD: Research and eData. For more information, please contact ISUReD@ilstu.edu. 


\title{
AN UNCOMMON SPLICE: SEEKING MUTATIONS IN THE LIFE-WRITING AND SHORT FICTION OF MARY BUTTS AND DJUNA BARNES
}

\author{
Susan M. George
}

77 Pages

May 2015

Immersed in a web of short stories, poetry, and supporting biographical and lifewriting sources, I investigate the narrative significance beneath and beyond two British and American modernist women authors. I evaluate sisterly connectedness between their literary production, publishing histories and life writings present in a specific culturaltemporal moment and genre: the short story. By looking on these unique, forgotten fictions through a new materialist lens, I argue for their short fiction's greater inclusion in the canon of women's modernism. Chapter I tests correlations between two authors undergoing the same stresses, alienations, joys and desires by taking up tenants of material theory in that exploration. Chapter 2 explores a space of cultural and literary incubation in Butts's writings. The natural, supernatural, abstract and material selves presented in Butts's short stories are always liminal. In Chapter 3, Barnes's enmeshment with Hank O'Neal and her magazine fiction is connected across decades. Barnes works within a genre of fiction while still redefining and undermining it principles, illuminating the way gendered modernism has potential for new, inclusive meanings. If modernist writing asks us to read through and around content, to the unique 
and evolving writer's subjectivity at the center, Butts and Barnes were a few of the first women modernists to attempt it. 
AN UNCOMMON SPLICE: SEEKING MUTATIONS IN THE LIFE-WRITING AND SHORT FICTION OF MARY BUTTS AND DJUNA BARNES

SUSAN M. GEORGE

A Thesis Submitted in Partial Fulfillment of the Requirements for the Degree of

MASTER OF ARTS

Department of English

ILLINOIS STATE UNIVERSITY

2015 


\section{AN UNCOMMON SPLICE: SEEKING MUTATIONS IN THE LIFE-WRITING AND SHORT FICTION OF MARY BUTTS AND DJUNA BARNES}

SUSAN M. GEORGE

COMMITTEE MEMBERS:

Hilary Justice, Chair

Cynthia Huff 


\section{CONTENTS}

Page

CONTENTS

CHAPTER

I. INTRODUCTION 1

II. FIRST FEMME MAUDITE: AN EVOLUTION FOR MARY BUTTS 9

III. CO-AUTHORED AUTOBIOGRAPHY AND NORMALIZED GROTESQUES 36

$\begin{array}{ll}\text { REFERENCES } & 74\end{array}$ 


\title{
CHAPTER I
}

\section{INTRODUCTION}

\author{
"The writer, Edouard Roditi, remembered "two very \\ strange writers in Paris... They both led very odd solitary \\ lives - extremely neurotic lives.", \\ Mary Butts: Scenes from the Life, N. Blondel 135.
}

The metaphor of mutation is confusion and a puzzle, an interlacing and a relocating of ideas. It is a call to reexamine a cultural study of women producing knowledge in communities by the power of resistive writing practice. This thesis begins a continuing effort to develop a framework of the Modernist woman's potential for agency in her own work throughout the process, act and materiality of writing itself. This journey is one of deconstructing barriers between so-called specialized women's fiction and Modernist writers exemplifying general themes of their movement. Both depend on the materiality of their circumstances and surroundings. I ask, where do correlations occur across experiential women's writing in the urban and natural spaces of twentieth century Britain and America? The potentiality of new paradigms like these are altered by the presence of an order not yet proven, in which binaries play a minor role, in which a 
revolution of thinking might any day occur to map Modernist struggle along alternative lines of thinking.

Literary Modernism in particular has varied and oftentimes strict modes of definition. They emerge rather reliant on fame produced by a few well-known writers at the expense of the peripheral or noncanonical. My questions become "what evidence is there to argue for the existence of a more inclusive Modernism and where are the signifying writers of such phenomena? What tools can be used to chisel meaning out of solidification, out of what is already known?" Ultimately, if women's writing of the period between 1920-1939 has any substantial merit outside the gender-based 'specialized niche', feminist materialism and New Materialism can be used to reverse its depreciation.

To that purpose, I have focused on two Modernist woman writers who, according to first person accounts, critical discourse, and even the cadence of their writings and lifewritings, had no intention of remaining marginal to their movement. Djuna Barnes and Mary Butts fashioned work as intentional phenomena, flaring and dying in the consciousness of their reading public over the duration of decades. Whether it is true or not, Butts and Barnes believed in the security of their future distinction and, like many writers of the Paris community, jealously paralleled their output to that of the milieu. They believed their work on par with their contending contemporary male writers. It thus becomes obligatory to find out who and what they were, not in contrast to well-known Modernist writers living in the same community, but independently, in order to create new, definitive models of Modernist short story writing of the period and these authors' 
formative role in Modernist knowledge production. Peel back the corner, crack the window, and begin to bridge the gap between life-telling, reputation and obscurity.

By seeking life-writing as reflection and connection to fictional output and giving Butts and Barnes their autobiographical due, we can strike rich and fertile ground for alternative discourse; locate lives and fictions outside and above dichotomies of the social and material, or natural and manufactured, to map a larger network of bodies and minds coexisting in the fray. Principally, these writers can be considered greater than "other" and more than marginal. I chose writers considered "one-work-writers." British writer of novels and short stories Mary Butts published "The Taverner Trilogy" between 1925 and 1932 while Djuna Barnes's Nightwood appeared in 1936. Definitive, critical recognition across these novels, but both writers wrote substantial collections of short stories as well. Unlike Virginia Woolf or James Joyce, who had considered the short story form a testing ground for the novel, Butts and Barnes were enormously proud of their short work collections published in Paris and New York based literary magazines such as The Little Review, The Dial and the transatlantic. Some invariably went unpublished. Mary Butts, surprised at the ease and relief she felt writing her childhood memoirs The Crystal Cabinet (1937), wrote in a letter that her success arose from "using the short-story technique...[to] fuse them all.” Published only a year before her death, her full-length autobiography was prepared nonchronologically, built into a series of childhood impressions; and was a genuine Modernist autobiography. She considered the technique of short story writing a sacred task, enriched with delicate skill and feeling and just as vital as novel-writing. They saw their work as important to the movement. Djuna Barnes and Mary Butts strove to make space for their precise vision of Modernism as it cloaked 
Paris and London in the 1920s. That space did not always align with the sentiments of other writers, or the content of their rivals' work.

This kind of research does contain several unknowns. These are relatively unknown writers' works. Their short works are unknown and are usually given critical attention as part of a larger study of their work and lives. Superficially, Mary Butts and Djuna Barnes can be considered challenging Modernists on par with T.S. Eliot, Ezra Pound and James Joyce, but the frustration of their writing should be partly embraced in order to make sense of its meaning. Sometimes, confusion is an end-goal, rather than a roadblock. Unearthing life-writing as a mixture of confessional honesty and subtly staged fabrication confronts the reader with the genres fluidity in the face of revelation. This balance bleeds into techniques of plot and setting inconsequential by texture, character development, sense, style, feeling and philosophy. A short story can be classically "Modern" while still unfolding in layers of encouraged confusion. Their short work in particular comprises all the tropes of classical literary Modernism, but with something closer to the edge of transformational fiction. They both worked hard to catch the soul of an image in a short period of time, the time it takes to read a story. Thorough research exists on liminality and imagism in Modernist storytelling. Barnes and Butts should be welcomed into its realm.

My argument, then, calls for an ongoing cultural discussion threading throughout selected short works. Their stories are densely packed, sometimes mysterious, or "hummingbirdlike." Their liminality is likely countered by their immediacy, power and resonance. Barnes's biographer Phillip Herring notes, "there is a quality of strangeness in a typical Barnesean story that lingers in the mind long after the details have begun to 
fade" (Herring 7). The sense and materiality of the story, its deep, mysterious message, seem to erase the importance of plot, character, and setting at times. The story itself is fabrication and fabric, is textual and textile. These texts in particular allow an appreciative confusion and respect in the face of an unreliable narrator. These writers confront the reader with the confusion of conscious life. They demand we read through and around content, to the unique and evolving writer's subjectivity at the center. It leads me to another developing question. How can a scholar seek the presence of complexity in the material world without confusion or obscurity? The work of Barnes and Butts target those doors and windows.

Mary Butts and Djuna Barnes wrote for similar audiences and under similar circumstances, but their writings remain singular. In the next few pages, I argue for a greater inclusion of their short fiction in the canon of Modernist fiction emerging from Paris and London. To justify this inclusion, I will be using feminist material theory to contemporize and explain my choices. I want to test correlations between two writers undergoing the same stresses, alienations, joys, and desires by taking up tenets of material theory in that investigation.

Barnes and Butts often position characters as decentralized in the narrative. Often they appear as vehicles for a larger message. Barnes and Butts repeatedly negotiate female and male selves in the natural and unnatural, urban world. They both are simultaneously obsessed and repulsed by the existence of the natural world as it exists in an increasingly alienated and industrialized landscape. Material feminist theory argues for nature as "an active, signifying force; an agent in its own terms" (12). It allows one to recognize blurring boundaries between the natural and urban, concepts assumed to be 
permanently separated. These writers repeatedly have characters negotiate these boundaries. They are particularly invested in the language of enmeshment and evolution. Grosz notes "evolution and growth, in nature as in politics, are precisely about overcoming what has happened to the individual through the history, memory and innovation open to that individual" (41). She also calls it an "evolutionary unfolding" (40). I use her tactics to "unfold" the patterns to politicize matter through the way Barnes and Butts tell their fictional and autobiographical stories. In simplest terms, the theory equips one with a tactic for reading these specific texts that incorporates both cultural and material forces.

An emerging modern world builds new bargains for women writers to write in shorter genres. Codes of gender, nature, war, isolation, the body, employment and linguistic tradition are scrutinized, remade or abandoned. Methods of life-writing accomplished in upheaval begin to break from the past in new ways. For Barnes and Butts, journaling, assisted co-autobiography and published memoir play a role in their development as Modernists. For example, Mary Butts wrote both in her journal and published a childhood memoir to further her publicity. Barnes's life, on the other hand, was observed as it happened. These observations were published as "memoir" under the name of another. Life writing is inextricably tied to publishing histories, needed reputations and an obsessive need to understand the "true author" behind her fiction. Mary Butt and Djuna Barnes are Modernist writers working outside the definition of Modernism and their life writing is confirmation of it. A closer evaluation of densely packed language, cultural reference, and unique stream-of-consciousness styles can only benefit a larger discussion of women's Modernism. By the nature of the writer and her 
genre, the conclusions can only improve on what is already known. "To remember the stories," Ashbery writes, "necessitates rereading them; there is no other way to hang on their breathless skittering as it evolves before us" (xii). By the world "evolves" we know Barnes and Butts imagined literary Modernism as something different than the majority.

For these writers in particular, collaborative biography comes into play. I intend to examine, through a collection of autobiographical and biographical materials available, to measure where Barnes and Butt have life experience in overlap with their fictions. This thesis calls for a reconfiguration of meaning in these particular women writers, whose lives are so entwined with publishing history, public persona and personal vision. These fictions are, on the whole, experimental and uncommon. Enter, then, an 'uncommon splice'. Butts and Barnes are two new species of Modernist, comprising of a collection of experiences, genres, grotesques, inaccuracies that exist outside parts of the movement. While definitions of Modernism cross and recross, Barnes and Butts deserve a more significant space with the chaos. They understood the power of nature and bodies, the truth value in autobiographical experience and in fiction. When genes cross, when two plants come together during the moment of experimentation, the new plant must benefit both to create something fresh.

Barnes and Butts do have writings and writing personas enmeshed in the gendered shaping of minds and bodies. When and where does that shaping reveal itself in their writings and to what purposes? I see this formation as a metaphorical evolution of writings, as a negotiation between writer, character and reader. The natural, supernatural, abstract and material selves presented in their short stories write women and men as products of a transitional cultural moment. Even male characters become conduits for 
female angst and uncertainty in a short span of time. I will evaluate evolutions where they occur, where they present a particular Modernist voice separate from the familiar mainstream. A mutation is confusion and a puzzle, but it is also the piece evolving on the strength of the whole to ensure the organism's survival. To this end, I am seeking writers surviving and producing at the threshold where the physicality of writing enmeshes with form, culture and gender. From the troubled roots of dominant knowledge to canopies of complexity and difference, I am attempting to categorize undiscovered species of women's fiction. 


\title{
CHAPTER II
}

\section{FIRST FEMME MAUDITE: AN EVOLUTION FOR MARY BUTTS}

\author{
"I have the makings - the materials to hand - collected \\ from a miserable youth - for a severe, entrancing, witty, \\ profound middle-life. I am learning my trade. I am twenty- \\ nine...I have recentred my ego outside my cadaver. I am \\ learning to taste what I swallow."
}

The Journals of Mary Butts, 13 January 1920

British writer Mary Butts began her childhood autobiography The Crystal Cabinet: My Childhood at Salterns on January 24th, 1935. It was two years before her death at age 46. After a lifetime of repressed memory now resurfacing in her short stories, Butts felt she had a score to settle with the people who had raised her, her mother having been an overbearing, conventional presence in her life. On the process of its writing there is little primary evidence in a score of journal entries, "probably because, unlike her other books, its writing was not difficult" (Nathalie Blondel 372). Indeed, during its completion, she wrote exclusively to her friends. She marveled at her ease in writing it. It had been more difficult to write fiction. She was reserved, though, in her divulgences. Several real people would be implicated in its publication, including her mother and brother. But in general, friends and acquaintances liked her and her writing; 
one visitor described her as "a personality with red hair, a little melancholy, blue eyes and good looks and wild recklessness, and a fallen-angel fascination” (Blondel 373). Th freedom of expression available in her published and unpublished autobiographical work can begin to open a door on meaning in her fiction. The last decade had seen the publication of three novels and abundant short stories. In 1937, she might have recognized her impending death. Numerous health and relationship troubles pursued her to Sennen, Cornwall after a few celebratory Paris years. As the result of unregulated diabetes and continued drug use, she died of complications due to a pancreatic ulcer in the fall of that year.

The major events of her life influence entirely what and how she writes. The popular reaction to her published childhood memoir is the first indication. Obsessed with a nostalgic natural sensory memory of her past and with a need to expose the world to the constrictions of a late Victorian childhood, she wrote her youth to gain reputation in old age. She positioned herself within the material world by the trauma of childhood and the haphazard poverty of her middle years. Through a combination of personal journaling both intended and not intended for publication, we can situate Butts as an important British Modernist. At each stage of her life, she was committed to her flourishing talent as a writer and her significance to the Modernist movement happening around her. She was arguably as good as, if not better than, than any of her male colleagues, but was resigned to a fate of posthumous fame. Even in 1927, some years before her last two novels were published, she admits in her diary, "T. S. Eliot, with his ear on some stops of English speech which have not been used before, the only writer of my quality, dislikes me \& my work, I think.” Butts sensed a connection, possible spiritual, between his 
writing and hers. "On its negative side," she admits, "The Waste Land. Up to now, he has been before me with my titles" (Butts "Journal" 276, December 25, 1927). Earlier in her diary, before The Waste Land's publication, she mentions the title, with some excitement, for a possibly short story.

In addition to a daily diary she had kept since 1916 , she wrote her memoir as a living testament to her family; those people who had subconsciously motivated meaning behind her writings. She was cursed by her disproving mother and adored by her father as she roamed the downs around Salterns in Cornwall. She decided not to develop The Crystal Cabinet, her memoir, along one theme alone, but many, fusing those themes together like an anthology of short stories. She held her life up as important enough to be offered to the future, conceivably to make some sense of the "machinery of life" and the "particularly allusive and elusive mingling of the contemporary with the classical, the literary with the everyday, the expected with the unusual." (Foy 34). She composed lifewriting with the same fervor and imagination of her short stories. Her readers wanted an authentic account of her childhood from her own perspective. Unlike her fragmented, expansive diary, which was misspelt and scattered in its lines of thought, The Crystal Cabinet was composed and edited for immediate publication, written furiously in the space of a year. She wrote this memoir through a new genre; a series of interconnected short stories unlike the classical linear narrative of time and growth. To this form of writing she had felt most connected after her first novel's publication. The traumatic and mystical childhood she details in The Crystal Cabinet: My Life at Salterns, mirrors many of the themes and ideas she uses in her short fiction. While the memoir itself is meant to 
be an authentic account of her life as a child, she used her journals to deconstruct those thought-processes most relevant to her fiction.

The Crystal Cabinet was published to widespread acclaim. Some months after her death, it became her most popular publication. However, its reputation did not prevent Antony Butts's resentment. "My sister's book contains innumerable distortions or blunt misstatement of fact," he writes, "which it would be out of place to single out here" (Blondel 428). He mentioned principally the infamous, unconfirmed scene of their mother, Mary Jane Butts, ordering book-loving Mary to haul her deceased stepfather's library to the woods to be ceremoniously burned. At this point, the line had been observably blurred between "novel" and autobiographical piece." It was known as "neither a collection of reminiscences nor a formal autobiography," but, "we are brought back and forward in time, everywhere incidents and impressions...bearing upon the mature life and mind of the narrator" (Blondel 426). Butts's fiction was incidental too, and her short fiction in particular is formed around the idea of "developed impression" in which an abstract idea, a magical idea emerges through the process of storytelling or lifetelling. Life and fiction were equally true.

Mary Butts did cherish her brother, an accomplished literary critic who might not have understood her motivations or methods in writing. But she fully embraced his homosexual identity and clung to him through hard times. Disgusted by inaccuracies in her memoir, Antony Butts states, "She is a bad woman - pretentious - I can see no merit in her books - pretentious. She corrupts young men. They are always committing suicide" (Blondel 430-1). He wrote specifically of the bisexual Cecil Maitland, Butts's lover, whose habit was threatening suicide on a weekly basis. 
Having very much believed in the supremacy of English myth and the prominence of classical knowledge in good Modernist writing, she wanted to blend the mysterious, ritualistic nature of outdoor spaces to the urbanized, everyday space of the city, structured and filled with manufactured objects and preserved artifacts. Through her diary, she craves "something magical," meaning something structured and embedded, yet allusive, in the experiential every day to make it more than ordinary. These intentions made The Crystal Cabinet a vessel for such pairings. Butts called it "Rather an explosive document, [but] "it all depends on how far I am remembered." Reviewers praised the poetry and genuine intent by which she painted her family members, but Butts's compulsion for divulging "explosive" family secrets might not have been as strong if she was less confident in her potential reputation as a writerly genius. She was as sure about her fame as Virginia Woolf (Wagstaff, The Crystal Cabinet 281). Like Woolf, Mary Butts desired a personal-made-public record of her life. With a published memoir and 21 year journal in her repertoire, Butts must have believed her own life worth remembering. Why, then, has she fallen into obscurity? It may take more than self-preservation to endure into the future. In 1998, Nathalie Blondel wrote an extensive biography of her life; Mary Butts: Scenes from the Life. It is invaluable research into her short stories. Two years later, Rosyln Foy published Ritual, Myth, \& Mysticism. A rare scattering of articles exists, while August 2014 brings Mary Butts and British Neo-Romanticism: The Enchantment of Place. Each of these writers holds a particular perspective on Butts using unique methodologies. By using a new kind of perspective, and seeing her work in light of her life-writing, her diary, and a new set of theories, some of her rich and complicated life and short work can be brought forward. 
A meaningful bond between Butts's fictional pieces and her life-writing is problematic the texts are mean to inform each other. The difficult process of producing fiction is documented in her journals, the intricate struggle between materiality and spirituality, magic, psychology, and the confusion of relationships and institutional religion. Butts wrote her life in order to in order to compose higher quality fiction. It may not be necessary to seek information or intent btween life-writing and short story. Lay out each as a genre unto itself and their importance to each, to Mary Butts's chaotic life, is finally gleaned. The Crystal Cabinet was written, in part, in order to secure a crumbling recognition amongst readers and friends of her literary worth, a grave private concern she had as those writers whom she considered her equals gained on her fame. That fight for acknowledgment and intent found in her life-writing were insufficient, were nothing compared to the power of continual publication in the literary magazines of Paris and London. Endorsements from T.S. Eliot and Ford Maddox Ford, editors of prominent magazines, would have gone a long way to secure her place among Modernist writers. Her perceived personality disorder alienated her from her contemporaries. Barbara Wagstaff notes that "it seems the intensity of her personality and of her work got in the way" of making emotional and literary connections to that gateway, T.S. Eliot, who had disapproved of her obsession with the English countryside in her fiction. Virginia Woolf dismissed Butts, labeling Armed with Madness "an indecent book." Bloomsbury thought her pleasant, but odd and standoffish. An evident discomfort existed in critics of her work. Wagstaff, in her conclusion to Butts's memoir notes she "treated decadence and the sacred with the authority of a male writer. The greatest degradation and the greatest 
sanctity often merge in her work, making both those who believe in God and those who do not uneasy (The Crystal Cabinet, Wagstaff 281-4).

To not only unsettle the religious but the irreligious was a dangerous path for a Modernist. She had religious and political convictions, but used her writing in order to explore them as phenomena, as witnessing, and not as a soapbox for particular philosophies (Butts, Journal 182). In this sense, she sought a style of harmony between opposites (the religious and atheist, the witnessed and the intuitive) that had yet to be reconciled. Her early entries explain this coming together through the concept of the third perception. In an early, ambitious, April 1921 journal entry she writes: "I want to make this world into material for the art of writing. I want to observe the pairs of opposites, remembering that that which is below is as that which is above. From this I wish to formulate clearly the hitherto incommunicable idea of a third perception. This is a perception of the nature of the universe as yet unknown to man except by intuitions which cannot be retained $\&$ by symbols whose meaning cannot be retained (Butts, Journal 182). The concept of a "third perception" unsettles the oppositional binaries of urban/natural, man/woman, abstract/material existing in other fictions she had read. She believed meaning was material, and always already there, ready to be known. Conflict, the supreme subject of fiction, is split open by allowing perspective to alter, change, and grow toward a landscape of solutions. The limits, the frustration of oppositional pairs had to be addressed. The adaptive nature of a new spirituality, brought forward by a fresh occultist fad, would guide her, at least for a while, to higher forms of meaningful experience. 
This eye for the sacred unknown stemmed from an ecological reverence for the land. This notion of creeping natural worlds growing up into urban spaces and consciousness can be mapped through her short fictions, especially "Widdershins" and "Brightness Falls." She held deepest love for the countryside, especially her childhood home of Salterns in Poole, Dorset, once a lush natural area and harbor transformed by 1920s and 30s tourist development, a fact that caused her some agony. The family mansion at Salterns was later sold, its contents auctioned, in order to pay Butts's considerable debts. But of Dorset, she wrote "The county where, if anywhere, the secret of England is implicit, concealed, yet continually giving out the stored forces of its genius" (Foy 42). The power and force of the natural, material world connects with the concept of cultural and material presence embedded in the physical transformation of the landscape. Butts's obsession with the magic "rings" and mounds of prehistoric Britain and her witnessing of the mechanization of land use is reflected in the dogged nature of her characters fleeing to and from such transformative places. Humans never land in the natural world able to control it as they wish (Foy 45). Where and when this occurs will emerge in the next few pages.

Mary Butts amongst the clever milieu of Bloomsbury and Gertrude Stein's salon gatherings was an awkward scene. "Glimpses of Mary Butts in memoirs of the period suggest how substantially her exuberance and intelligence contributed to gatherings, but she always stood out, a little apart." She had "much remarked-on bright red hair...[and] original behavior" but she also had "awareness of what lies just at or beyond the edge of the perceptible" (Foy 282-3). This was disconcerting to readers familiar with traditional narrative structures of Thomas Hardy and Arnold Bennett. She felt part of the "movement 
away from the writerly and coherence of narrative commentary to decentered narrative...an emphasis on the fluidity and discontinuity of identity, often expressed through the 'stream of consciousness.' The term itself comes from May Sinclair's 1918 review of Dorothy Richardson's Pointed Roofs, a novel of female perception, which is a "startling newness...for getting closer to reality". Butts's short fiction in particular, is marked by "disruptions of chronology and a vigorous engagement of the reader in the difficulties of interpretation" (Foy 72-3). Therefore, her characters do not just embrace English myth and magic, but juxtapose it with alternative ways of accessing a fragmented past. This style of prose is defined by its insistence on its own newness, its edging to the brink of the "real". Moral dimension, while still important, were only kept in order to obliterate it. The presence of a deep, mystical power of perception, of real-to-life decentered narrative were to Butts, only essential to the best and truest storytelling.

These avant-garde explorations in form were initialized by her father's unconventional library at Salterns and some study at St. Leanord's School in Cornwall. Like other upper middle class women, Butts did not attend university as did her brother. Nevertheless, history and religion were more than mere subjects, but a "physical reality" that affect her everyday life and her writing. History becomes, in this sense, a material object to be explored, handled, witness and described (Foy 38). Not only history but the power of "the occult" influenced her method of short story telling. She treated "magic" as a "third perception," and as a form of study equal to science. 1920s magical study was slowly gaining faith-based legitimacy among upper class spiritualists and holders of séances. Many writers admired the occult's mediation between the factlessness of faith and the cold reality of scientific discovery. It was another way, or to some, the only way, 
in which reality was perceived outside human influence. Religion she rejected, but magic would manifest itself materially, again and again, through the world. She called this natural power "phenomena," a new materialist term describing material forces outside human influence, which none the less influence human perception. In each story, she fears "the despirutalization of the material world" through Modernism's rejection of conventional spirituality tied up in rituals of the Church of England. "Nothing with take away from me the sense of the terrific and absolute importance of phenomena" (Butts "Journal" 49) she declared. Phenomena, in the new materialist sense, are a sudden appearance, act, or event occurring in the midst of life without human explanation, yet is influenced by human action. Phenomena is a direct rejection of what Karen Barad calls "representationalism" which is a "reassessing [of] how we understand social phenomena, including the material practices which divide the world into the categories of the social and the natural" (Barad 24). Fiction is a representation of life. Mary Butt's fiction means to break down the barrier between the described object and the unpredictable object, person, or emotion itself. But this does mean we should "write matter and meaning into separate categories" as they become exposed to view. She separates representation (a fictional construct) from real social and material phenomena in order to expose the integral roles of the "human and nonhuman, material and discursive" (Barad 24-5). This phenomena occur by haphazard chance, can be feared, coveted, or worshipped. Virginia Woolf"s concept of the "moment of being" in her memoir Moments of Being edges towards its meaning. Phenomena is sudden and leaves a confused, fearful, shocking memory of what has occurred. Men and women in Butt's stories have "exceptional experiences" which "brought with them a particular horror and a physical collapse" 
(Woolf 71). She notes, "they seemed dominant, myself passive...It proves that life is not confined to one's body and what one says and does; one is living all the time in relation to certain background rods or conceptions" (Woolf 72). While "A Sketch of the Past" skirts the idea of spirituality and mysticism as explanations of phenomena, she and Butts both agree there is must be a "shock receiving capacity" in author and character alike.

Ultimately, to the contemporary reader, the concept of phenomena may seem like protoNew Age flimflam, but Butt's seriousness in spirituality was tied to personal truth value. Her commitment to the description of such bursts of perception preceded Woolf by 16 years.

Eventually, her study with the magician Aleister Crowley produced a book of magic in 1912 entitled Magick (Book 4) to which she was given co-authorship credit. But the progressing years produced a "gradual dissatisfaction with these magical experiments [and] their disregard for the material world" (48-49). Her own idea of the importance of materiality clashed with those flighty, abstract ideas found in Crowley's version of occultism. Abstraction and stream-of-consciousness in storytelling were important but must still connect to living people enmeshed in reality, not the otherworld of a pseudotheorizing religion. She did not want to write herself into another religion after twisting loose from Anglicanism. Her explorations in disruption destabilization and discontinuity upset readers of traditionalist prose. Therefore, "Butts never became part of any group that could ensure her a place in literary history, and though personal relationships in part may account for her failure to find support, it is more likely that the writing itself, in its uncompromising effort to read le message indéchiffrable, proved disconcerting" (Wagstaff, Crystal Cabinet 281). 
In the next pages, I select short fiction from Butts's archive that most aptly represent her struggle, the purposes of her life-writing and the styles of characterization, form and narrativity that most reflect her personality as an artist. They were written at different points in her life, the last having been published a few years before her death. Butt's writing is radical in its self-portraits and in her othered experiences. These explorations will shed light on the possible fate of Butts herself in the Modernist firmament and determine whether she was self-exiled from the Paris literary set or other entities were the final cause of her obscurity. Mary Butts's relationship to the occult was not obsessive, drastic or worshipful. She felt she might simply prove, through fiction, the importance of outside forces that shape the meaning of lives. She did not want to be accused of writing science fiction or indulging in the metaphysical. She hoped to legitimize the forces of nature she had known as central to storytelling. She wanted to fill in gaps of knowledge, like Freud, between what is known and the "third perspective" or the unexplained phenomena different people experience in daily life. Her short fiction was able to accomplish this through innovative form and language. Roslyn Foy notes that "her work certainly belongs among the work of other Modernist who challenged existing patterns of language and communication" (Foy 12).

Now to Butt's short fiction, where her personal expression blends into personal authenticity. Her short stories turn into a testament to personal experience with magic, the alienated natural world in the space of the urban, and the problem of authenticity. (Smith, Watson 237). Running parallel to Mary Butts's lifelong interest in the supernatural and occult, her story "Brightness Falls" was written towards the end of her life. After a few rambunctious Paris years with her husband, Gabriel Atkin, Butts was driven by concealed 
ailments back to Sennen, Cornwall, a tiny village, in order to regain her health. Estranged from Atkin for two years, and receiving no money, she hoped desperately that T.S. Eliot might publish "Brightness Falls" amongst other short tales to float her until Aitkin's return. She must have felt entitled to some recognition, having repeatedly sent stories in for publication to Eliot's Criterion, including this "Brightness Falls" and "Mappis Mundi," a story the Fitzgeralds cherished. Despite her agent's repeated submission of finished stories, Eliot refused to publish. Perhaps Butts felt her personal, lengthy relationship with Eliot justified publication of her stories. Eliot eventually wrote to Butts with a vague, marginally cutting response to her inquiries: "I should find it exceedingly difficult ever to refuse less welcome tasks of the same sort, particularly from people whose claim upon me would be rather personal than due to my admiration of their work" (Nathalie Blondel 414-6).

"Brightness Falls," published in a collection in the late 1980s, was nearly compiled with others in a published book in 1937. Her sudden death at 46 prevented it. In summary, the story itself unfolds across two landmarks; Lincoln's Inn Fields embedded in the center of London and Sigmund Freud's Psychopathology of Everyday Life (1902). Blondel calls it a "fictional repudiation" in which she "interweaves and refutes" Freud's most popular theory; the subconscious role of memory, forgetting, and word (dis)association. Butts blends her theory of material occultism into her study of early psychoanalytics. Characters create sinister word associations and forget the proper use of words in favor of other imagined ones whenever the "magical" world of London emerges behind the real one. Forces outside human control influence their actions at each turn. 
A.A. Brill introduces Freud's book with studied praise. He "throws much light on the complex problems of human behaviour, and clearly demonstrates that the hitherto considered impassable gap between normal and abnormal mental states is more apparent than real" (Freud v-vi). "Brightness Falls" reveals how the "abnormal" mind is not simply a manifestation of its own subconscious. Outside, material forces, especially built spaces and boundaries between spaces, influence a mind's association with certain words, memories, or indeed, unseen dimensions existing outside human perception. Lincoln's Inn Fields, where the story takes place, is one of the oldest, largest and most centrally located public green spaces in London. It is delineated by high fences, brick walls, oblique angels, and closely built structures. It becomes a material representation of nature in an urban space.

In simplest terms, the story's plot follows a few days in the life of Max and Parmys. The narrator, Max's unnamed male friend, listens to Max's story about the abnormal behavior of his wife, Parmys. An upper middle woman living in London, Parmys encounters and bonds with Cynthia, a supposed "witch" who appears to serve as occult student to a strange magician, Corandel. As Parmys is drawn away from Max and toward Cynthia's power, the story climaxes at Lincoln's Inn Fields where the alienated Max plays witness to a supernatural glimpse through a door on a parallel universe opened by some connection between Parmys and Cynthia. The two women, in turn, appear drained from conjuring it up before them. What are they? What do they conjure? Why do they become caught up in parallel world imprinted upon the real one? All unanswered questions. But spiritual dread soon subsides and the two women return to the normal world once again. Max, in relief, proclaims these phenomena "an enormous lark." Also, 
he tells the narrator, during the next few normal days "physically, they were so refreshed and lovely...they got livelier and livelier, out of their clothes and into them again; telephones, taxis, dancing somewhere, more mischief..." (Butts "Selected Stories" 217). Max then refuses to join them in their adventure across London. His reason for avoiding them is left to interpretation, but Butts's message is that Parmys and Cynthia are inherently equipped with a higher magical cognition which the uninitiated, Max, will unconsciously shun. Even Corandel, the magician-teacher plays a farce. He runs "at an oblique angle" from the scene and disappears.

In 1932, this story would have appeared quite strange. Its tone fluctuates between serious and playful as Max bickers with his friend over the deterioration of his marriage and his wife's obsession with a strange woman. It rejects the emerging Modernist notion that human interaction and emotion from witnessing is all in one's head, that human perception is the highest form of storytelling. The force of outside spaces, especially the natural placed within the urban; create doors into unknown knowledge or a "third perception." Butts experiments with the presence of the mystical in the everyday space of a park and claims that "mystic" people, especially women, can understand where and what it is.

In the traditional Modernist sense, the story's plot is secondary to the abstract idea Butts strives to convey. She writes in her journal, 'I had studied 'occultism' \& found it stirring, but unsatisfactory, a maze of blind alleys. . . . After five years I realize that I have observed all my life, a series of phenomena ... which I now believe to be part of a series though the connection between them is not clear (Butts "Journal" 22). In "Brightness Falls" the unnamed male narrator begins by admitting, "There is no head or 
tail to this story" (203) and also "This story fits nowhere." (205-6). Even after witnessing a strange, unexplained transformation in his wife, Parmys, he refuses to make connections through either reason or magic. The narrator even refuses to believe the authenticity of the story at the beginning of its telling. It is impossible that Parmys, a wife, would behave in this way. Like Butts herself, the narrator refuses to believe Max's perception of his changing wife without strict evidence, allowing the reader to pass judgment on its truth value. Actual truth stems from soil furthest from perception.

The unnamed narrator becomes a narrative biographer, telling and retelling an experience in which the teller is both part and apart from the story itself; a distanced witness to supernatural phenomena. As Max recounts to his friend the increasingly strange behavior of his wife, he nonchalantly attributes it to witchcraft, spells, or magical forces beyond his knowledge. "All women's occupations," he admits dismissively (Butts 205). Parmys, his wife, is labeled an ordinary woman. While Max cannot believe his wife would practice magic, he reflects on "the number of times the impossible turns up in a man's life" (Butts 204). Max's practical, forceful personality is juxtaposed against the normative and spiritual coinciding in the person of Parmys. Max is content to believe in unexplained, ridiculous phenomena (such as a door opening to another plane of existence) without actually attempting to break down its mystery, even enough to refute it.

In Jane Bennett's Vibrant Matter, she mentions “that human experience...includes encounters with an outside that is active, forceful, and (quasi)independent" (Kindle Locations 262-263). The style of occultism Butts studied was a philosophy of mind, almost a religion. Her unique vision saw magic as more 
genuine to experience, more material and present. She pays tribute to these material forces in the green space of a public park surrounded by urbanization on all sides. Even in the metropolis, the power of nature lies embedded at its center. The irony comes from the fact that an out-of-body experience requires a body and experience in order to be real. Mere abstraction cannot count. A “magical” world is only revealed by Max's witnessing. Without his disbelief, the map imprinted underneath London's actual map would never be revealed. The moment of confusion finally comes when Max witnesses Parmys and Cynthia on the lawn and "there was something following him that [he] just did not see." He recounts:

"I couldn't stay beside them, because they were half in, half out of another world. Also, they changed. Before there had been Parmys resolute, and Cynthia distressed; now there were two shapes, abstractions of women....Everything was enhanced to fantasy and breaking-point. They never seemed to me to be quite inside" (Butts "Selected Stories" 214-5).

In the 1920s, Lincoln's Inn was a wide swathe of open grass embedded in the heart of a bustling city. It was naturalness in the heart of the open city. It was nature forced into the space of the city. "Every leaf is like a word you couldn't catch" (208) Max says of the space of the ancient park. He begins to perceive little things that one does not ordinarily see which affect our lives and as a strange problem or misunderstanding of the inherent power found in his wife. He notices that "Parmys looked coarse... was like an archaic goddess stored with raw power... Something that is foundation of wise woman and child" (213). Butts is calling upon the ancient mythology of Britain and bringing it, naturally, to the space of the city. Maps, places and spaces become very important. There 
grows a connection between detailed description and vague, powerful meanings just beneath the surface. Eventually, Parmys and Cynthia find themselves in a separate scene, conjured up over the space of Lincoln's Inn Fields. When Max tells his male confidant what rites his wife and friend were conducting on the windswept lawn, he says "It may have been hypnotism, and hypnotism may be anything. I was speechless too with trying to make up my mind" (216). Very puzzling. How does one account for an occult rite in which two people participate in its imagining and a third person, Max, is also witness?

The puzzle of the story is in Butts's meaning. Mysticism, to her, was not Gothic or ghostly, but an actual force of nature embedded in the everyday, the material summoned up by the bustling world of the domestic everyday: omnibuses, cars, advertisements, traffic signs, bodies moving, grass, wind, sun, the objects populated a space. A thin veil, sheer and moveable, connects experiential life with something deeper and eternal. She did not believe in a diaphanous spiritualism, in which the supernatural world is ephemeral and vaguely explained, but something concrete, that can be figured out through investigation. But the problem with phenomena is it does not exist by proof. Samantha Coole calls it "generative, self-transformative, and creative materiality" which does not "rely on any metaphysical invocation of mysterious, immaterial forces or agencies" (Samatha Coole, Kindle Location 1217). Phenomena do not exist inside the metaphysical world, but the actualized world, the space and place of green lawns, trafficfilled streets, conversations between friends and cafes. Butts allows Parmys and Cynthia to have broken through to a deeper layer of knowledge. Mary Butts seems to be belittling this fad for occultism by somehow legitimizing the parts that might prove beneficial. These metaphysical "slush of theosophy: auras and reincarnations" Max finds rightly 
distasteful (204) are replaced by something else. It becomes almost like a case for intelligent design in a chaotic world. Butt's spiritual convictions evident in this story border on utter confusion. She offers up a stream of consciousness entry in her journal to mirror Cynthia's alienation. Butts explains it as best she can:

Some things are part of a huge significant design — another back-door for God. Magic things are the designed things then? The magic quality is in an existence where there may be design...There is a moment when existence has another quality. Sometimes then we see structures, sometimes there is a new perception that can be co-related, sometimes a phantasy which can be related to nothing, \& is terrifying or enchanting. The psychologists must name that quality and account for it" (The Journal of Mary Butts, 196).

Ultimately, Cynthia and Parmys experience on the lawn at Lincoln's Inn is a door to perception. In 1924 Mary Butts already accounted for the fact that more work had to be done with these concepts, especially by the likes of Aldous Huxley. She already had some reservations about the powers of psychoanalytic theory to explore and explain unreliable human perception and memory. She allowed for that "relation to nothing" which does not need a meaningful connection to every human behavior in order to make sense or be beautiful or helpful. Does a memory or phenomena need to be "called up" by the mind, accessed from a archive of data in order to be real? Or do natural forces outside human control embody that memory? Sometimes no explanation can be given for the presence of phenomena. This becomes a case against psychoanalyzing behaviors or mystifying them with religion. This reveals Butts's persistent questions about the nature 
of human design, intent and her own role in relation to other humans. Like Parmys, she had accounted for, in the last five years, a whole slew of similar experiences, along the moors and slopes of Cornwall and the urbanization of her beloved Salterns. An ecological protest in the space of London is unearthed.

"Brightness Falls" piqued the interest of reading audiences, but Butt's failings would soon mount after initial success. Before discouragement had set in over Eliot's disregard, Butts's excitement overflowed after the publication of "Widdershins," (1924) in Ford Maddox Ford's Transatlantic Review. She was ready to explore again the materiality of her world. Her contemporaries Djuna Barnes, Jean Cassou, Hilda Doolittle, Ernest Hemingway, Selma Lagerlof, Jean Rhys, and Gertrude Stein had all been published or would be published in it, along with Joyce's Finnegan's Wake. She was paid $£ 4$ for the 3,000 word story. In it, a self-exiled man named Dick Tressider returns from Cornwall and his country estate to "his beloved London" (Butts 142). Over forty, wifeless and something of a mystic or self-named prophet, he seeks out Daphne, a girl he once loved. Traveling across a completely transformed London, he first visits his friend Eden, a publisher, in order to drag him to the British Museum. A curious conversation takes place in which Dick presses upon Eden the "magical" significance of artifacts at the museum. Dick is fueled by a fresh hatred for the commercialization of London and Daphne's apparent coldness towards him. The city and woman are "all strange and changed and the woman whom he loved now quite remote and estranged from him" (142). Contemporary reviewers read the story as "a corrosive study of an egoist who wanted to get men to see their cosmic significance," whatever and wherever it may be. It was also received as "an admirable and dispassionate perception - a perception which 
indicates more than intellectual integrity" (142). To Butts, this might have been a gentler way of admitting the story was complicated.

This does not mean it is complicated to the point of frustration. In typical Modernist style, Butts creates and moves a scene deftly from one area of London to another. Characters always appear to dwindle. Dick's actions, his comments on the state of modern city life, his distaste for urban trivialities appear to gain weight and shape. His restlessness takes form in the museum objects he observes with Eden at the British museum (Blondel 142). Average citizens cannot know the triviality of their lives. Like the story before, its summary appears to run counterintuitive to what Butts's actual message could have meant. Again, the plot points of the story are less important than the underlying theme, which seems to emerge through the characters. Dick struggles to understand the mystic mystery of urban life in London who, like Cherry, is already beginning to forget the material consequences of war: "In individual action there were moments of a peculiar quality that expressed the state in which he knew the whole earth could live all the time, and settle the hash of time, progress and morality once and forever" (193). Dick has strict ideas about how the world should and could be, including the life of the girl Cherry. In "Brightness Falls," Dick has strict notions of a woman's image. He begins to build an imagined Cherry and expects all the traits of a conventional English wife to reveal themselves in her character and body. Cherry, on the other hand, has no tangible interest in becoming a wife, or playing any complimentary role to Dick's wishes. Dick's concept of mysticism has him striving for masculine power.

The most vivid details of the story emerge as Dick recalls life in Cornwall through a serious of perceptive images: "There were moments, too, under the hills, breaking-in 
horses, when it came, the moment of pure being, the co-ordination of power" (193). Again, it recalls Woolf's concept of "moment of being," the shard of memory embedded through nonlinear experience. Unreliable and fragmented, Dick is encouraged to forget Daphne as an embracing confusion and frustration as a part of life. "The word widdershins is a variation on withershins, which means the direction opposite to the usual, the wrong way" (Foy 98). Dick himself is constantly at widdershins with the world. as he forces characters to come face-to-face with "their cosmic significance." Ironically it seems the abstractness of life, the present cosmic significance, can only reveal itself through the urban space of the city. There is disconnect between men and women, in which the old conventions are weighted heavily against the immediate needs of the present. Masculinity is constantly questioned, changed, transformed, and renamed. For Mary Butts's character at least, men are always in a constant struggle to seek meaning and personal, masculine subjectivity in a chaotic world, while women remain relatively calm in confusion. "Her female protagonists look to feminine archetypes in which they find a numinous source and center. They call up a heritage that offers a universe at once organic, sacred, and whole" (Foy 99). This sacredness is reserved for women alone. Daphne herself rejects Dick by taking a taxi halfway to a party and unceremoniously letting him out. Daphne's New Woman becomes, in this moment, a direct rejection of Dick's symbolic offer of marriage and convention.

He instead haunts the streets of London and futility wishes to "persuade all men that they were only there to illustrate the worth of the land" (196). In the space of the city he feels a loss of connection to the last itself and is "wounded, lost and longing." $\mathrm{He}$ 
"must find a way, which Daphne knows innately, to live in both worlds - the world of reality, or the earthly paradise, and the world of magic and myth. (Foy 99).

In a 1932 letter to her friend Hugh Ross Williamson, Butts had described "From Altar to Chimney-Piece," a nearly novella length short story as a "song story... whose real title is "The-Gertrude-Stein-Song... Of course I had to hide who it was, - fairly well - but I'd like to learn that depraved old creature not to monkey with the English language!." Others say it had the "the incoherence of a nightmare," was both "bad and mad" (Blondel 256). It was Butts's longest short piece. In the story, a youngish man named Vincent enters war-weary and society-weary from the English countryside to live in Paris, much like Dick Tressider in "Widdershins." There he meets a woman somewhat younger than himself named Cherry. Besides experiencing the life that Paris has to offer, he spends his time following Cherry doggedly around the city. He eventually arrives at an intellectual gathering hosted by a Gertrude Stein-like figure named Miss Van Norden. Through a strange encounter with horded religious artifacts at Van Norden's home, Vincent comes to realize the superficiality of salon culture, the superficiality of Cherry's love for him, and the idiocy of intellectual hangers-on or "society geese" as Butts names them. In the space of this story, Butts puts away a portion of spirituality in order to point out all the flaws of literary Paris. Butts relationship with Montparnasse was mixed. She named it "an American side-show and an alcoholic's parade" but also "not a bad copy of New York" (Butts 234).

The importance of place and space again here is evident. The materially creative space of the city eases Vincent's pain after a “just ended war...modulating, civilizing, evoking, praising, setting free" (Butts 235). But "the right bank of Seine belongs to the 
world, and the left bank to France" (238). Material lines must be drawn strictly between commercial Paris and artistic Paris. Vincent, who is not an artist or writer, must navigate the space of such a city. He enters the city with some resentments, hoping to spend his time gathering cheap art in order to decorate his family house in Cornwall, relishing Paris's "tangible treasure" (240). When he meets Cherry, she is "The freest of free things" from Missouri, who had "a sharp young appetite for everything" (244). With Cherry, "Vincent immediately forgot to think of himself as a piece of middle-aged war breakage, and tore around with her all night and half the day (244). But even in their carousing, a creeping fear comes over him. He wonders if Cherry is not "wholly an evil child" (261) or somehow both noble and innocent of mind.

Vincent is "a man to whom quiet power would have come in life" but then notes "they castrated me, after all...there must be a million or so like me" (238). As a veteran of the war, and a gentleman, Dick feels compelled to act a certain part. A reluctant English patriot, Vincent is a bastion of the old guard, with such distrust of the urbanization of England that he flees into an urbanized Paris. Vincent represents creation, power, and traumatized, traditional masculinity. Here Butts uses Vincent's character to brutally evaluate the style of Modernist writing popular in Paris at the time. She called the work of Stein a "reproduction of half-conscious thinking" in which stream-of-consciousness styling was used to excuse incoherent storytelling. She emphasized art that was true and honest, and not a pretense for literary tricks and ramblings.

The sacred power of material objects dominates as Vincent's strained relationship with Cherry crosses and ends at Miss Van Norden's salon. Vincent, who has horded the work of starving artists for his family house at Cornwall, is now drawn by the presence of 
religious artifacts kept as curio in a wealthy woman's home. He picks up an incense box, a chalice, all paraphernalia of the English country alter. With "some common metal, gilt, rough, traditional" but still, "the design was pure, the whole representing a flame or a star on fire, inset with a circular disk, rubbed silver-bright” (Butts 264). Once a part of the traditional alter-furniture of country churches, it was now "dried and cracked and the signature of Christ rubbed off at a touch" (264). The structure of faith is so transient; its meaning may "rub off at a touch". The object itself only holds power by Vincent's fascination with it, not its religious significance. Vincent's journey through Paris ends with the uselessness of forgotten ceremony. Now mere curiosity, its original purpose has been deliberately erased. Representationalism, the deep symbolism of country ritual is sacrificed to time, to urban secularization. As Christ is rubbed away from an artifact, Butts does not forebode doom for Christianity. She means to question the conflicting binary itself that leaves no room for either faith or intellect to live in harmony. Reduce now to an objet d'art, it may channel a new material power. While the old Anglican rituals were meant to inspire the soul to transience, the tool of such ritual has been sacrificed to the preservation of art itself, which becomes its own religion. An abstraction like faith does not suffer from a "desacralization" of its revered objects. The 'sacred' was akin to "a power, and in the last analysis, to reality" (Foy 104). The sacred life, now crushed by rejected love, by disaffection, by urban alienation, is preserved after its object's meaning is erased. Miss Van Norden only cherishes the object as a holder of memory, as an artifact to the past. The specificity of that time, place, or region is not relevant. An object's significance stems only from its owner's desire to own it. The 
owner alone gives it significance, while Cherry is invested in the "pretentious ritual worship of art" (262).

Mary Butts is building on an exploration of lives. She becomes incredibly sensitive to her surroundings, merging the problem of space and place, of truth and mysticism and of the sad, strange relationships between men and women. The physical and metaphysical are inextricably tied to each other. Unfortunately, like Parmys of "Brightness Falls," Cherry's mind and body prove inaccessible, as she is "carried into a world where he could never penetrate....Only the utmost height of passion would have given him the power and the insight, and that he had not felt...(261-2). Again, Dick is not included in the "third perception" of knowledge only shared by Cherry, who is a figure one cannot quite place. Dick wonders, "Was she real, or was she not? For if she was real, his real, she was too good to be true" (245). Both noble and innocent, evil and good, Cherry's character draws on a traditional feminine ingénue archetype while in turn refuting it. As a young American woman, Cherry appears to gain a surprising independence and freedom, subverting the Jamesian idea of the tragic expatriate woman.

Despite Eliot's refusals, Mary Butts was able to publish these stories and many others in various literary magazines in London and Paris, including The Little Review. Selections from Ashe of Rings appeared alongside the serialized version of James Joyce's Ulysses. Others were finally published a year after her death in Last Stories (1938). Her contemporaries were critically impressed with her work. They praised her use of ritual, myth, and unusual forms in order to convey some larger meaning (Foy 280). Her modern characters are made impersonal and abstract "by placing them in an adventure not entirely personal that has repercussions beyond their own lives" (Foy 280). In her works, 
women are allusive, boorish, frustrating, and magical, while narrating men appear resistive, depressed, and animal-like and move through worlds completely opposite to their philosophies. She wrote to be deadly serious and playful. As her journal shows, she reveled in frustration and ambiguity and told no moral tale. Admired by Aldous Huxley, Butts's “notion of timelessness involved exploring, conveying, and to some extent fracturing the boundaries between Time and Space" (Blondel 99). She was very much invested in the nature of the mind and its relationship to deductive reasoning and perception. In some ways, she was on the cutting edge of modern psychology and occultism, two philosophies emerging into popularity in the 1920s (242).

Butts short stories are a mystery. Without some knowledge of her background and philosophies, her writing soon becomes obscure and tedious. Critics resistive to her strange writing claimed it was "a stunt" and not worthy of her and also "confusing, irreverent, satirical, anachronistic, and bizarre.” They do not always place human control and human knowledge at the forefront. Butts writes, "Once I believed that human ideas or rights were the ultimate - if not the thing-in-itself — enough for us to go on with. I had standards, I knew the world did not 'live up' to them, but imagined that it wished to \& paid them more than lip service. I did not know the bases of human nature nor of what lies outside human nature yet affects it" (276). She was beginning to move beyond the space of human influence to the larger universe of unknown mutations. 


\title{
CHAPTER III
}

\section{CO-AUTHORED AUTOBIOGRAPHY AND NORMALIZED GROTESQUES}

\author{
"The books of this genius lady lie isolated and tremulous in \\ the world's shelves...they are imperishable not because \\ they are critical evolutionary linkage, but because they are \\ alive with the signs and energies of a terrible and beautiful \\ mind."
}

Thomas McGuane, A Festschrift for Miss Barnes on Her $80^{\text {th }}$ Birthday, 1972.

Hank O’Neil's co-autobiography Life is Painful, Nasty \& Short - In My Case It Has Only Been Painful and Nasty; Djuna Barnes, 1978-1981 - An Informal Memoir is a recollection of a fading legend, of a subject more myth than matter; the life of Djuna Barnes. O’Neil, together with Djuna Barnes, produced this unusual autobiographical document without her official consent. In it he examines contradictions between Barnes's invented literary persona, the reality of her everyday existence and the strange material grotesques informed by that persona. By the time of the autobiography's publication, the public had withdrawn its curiosity from her prolonged isolation in New York. This compelled O’Neal to seek out her current situation to find her true motivations for seclusion (O’Neal 193). While his published text raises questions about the ethical 
dilemma of co-authored autobiography, it reveals truths of Barnes's existence and enhances an understanding of her short fiction. Barnes did attempt to give readers what they had been seeking: her two decade experience in Paris before the war, but she quickly abandoned the project. The unpublished fragments of this rough autobiography or "memoirs" can be found in Phillip Herring's and Osias Stutman's Collected Poems With Notes Toward the Memoirs. Barnes simply would not attempt to publish a autobiography, though she tried to finish one. When the situation called for honesty in storytelling, she found herself writing about other people before herself. Her own past may not have lived up to expectation formed by the persona she had developed over the years.

Mary Butts expressed her motivation for life-writing in her autobiography itself. She knew herself to be a genius and needed the world to understand her permanence and importance as a Modernist writer through her own performed past. She sought renown through these means. If these are the usual authorial motivations for writing autobiography, Djuna Barnes, a very similar writer in style and content, is a person obscured by our own speculation. She made no published attempt at confession, description or fabrication of her own life. As noted, her attempted autobiography was published in the appendix of Collected Poems (2005) on pages 235-270 and remained among her archived papers along with her letters. "Some pages have been lost, presumably the first four, for the narrative begins on the fifth page," (Herring and Stutman 235). In the four miserly autobiographical chapters, she makes such comments as "Did France make Gertrude Stein? Well, her brother Leo helped (Phillip Herring and Osias Stutman 238). Also, "there you have Joyce, the Grand Inquisitor, come to judge himself and his generation. To question him was to receive a cold, terrible gaze. Joyce 
alone could question Joyce" (Herring and Stutman 238). The thirty-five pages of autobiographic account continue in uneven, but sparkling observations of minor writers and performers of her acquaintance, her illness in Paris, and the breakout of World War II. Is there genre classification for these scrawled pages? The life-writing's content is mixed-genre; its subject is not always Djuna Barnes. She plays witty ethnographer, eager nostalgic, and socio-political commentator, and not always a self-subject. In her recollections of war in Paris she recounts attempting to leave after war breaks out:

I returned to my hotel. There was no one to talk to, no friend left, and the only one I cared for was in Aix-en-Provence. My other friends were in London. Again my nerves broke, but I had to stand in line hour upon hour for permission to stay in France. When I inquired if the Comite Americain de Secours Civil could use me, I was laughed at. Americans were not wanted in France, and why on earth was I still there after nearly seven weeks? I said it was a very simple matter - I had no money (Herring and Stutman 263).

Her tone in these few pages is neither sentimental nor dramatic, nor particularly wedded to cool accuracy. After a stint in hospital, Barnes is sent home with an at-home care nurse who jabs her with needles as if she is "mending a harness" (263). The nurse disappears and is discovered washing her clothes in Barnes's bathtub (269). These scenes and experiences offer narrative promise unfulfilled by content. The first two sections, "Vantage Ground" and "Way of Life" are dominated by humor, are gossipy and celebratory. She offers lovely cutting descriptions of friends and acquaintances. The last two chapters, "Farewell Paris," and "War in Paris (1939)" are traumatic, as she details her increasing illness and her entrapment in Paris: 
"It started out with a fever and ended with a war. Through the fever and through the war I learned about nurses and doctors and hospitals and friends and acquaintances and little people in trouble that I had never thought to know. I learned of that slow disqualification that pride and dignity suffer when one fights to live through personal and impersonal attack" (263).

These excerpts reveal Barnes's potential as an expert autobiographer and a skilled teller of her own life. They reveal how Barnes maintained her sense of humor and humanity in Paris between 1939 and 1940. She may have felt guilty about her own obsession with gossip and with the lives of other writers. But she was equally willing to shame others obsessed with trivialities before and after war influences behavior. She describes maids standing at the dark windows of mansions abandoned by their mistresses. The American Embassy is known as the "second weeping-wall" where desperate ex-patriates attempted passage home. Paris "stood before her like a friend with no memory" (267) and the last line reads: "Back in Paris are a man or two, a woman or two of my own race who have said that they would run like mad if there was a war, but they are playing cards" (270). In swift, perceptive prose she begins to build a remembrance of the past. She is able to cover a range of emotions and themes in only a few pages. Unfortunately, the Barnes Persona got in the way of her own autobiography. Barnes had a seemingly deep obsession with the observable lives of her contemporaries, a sign of her background in journalism. Coupled with a vague fear of censure and a self-inflicted shame, these passages represent an author incapable of furthering bad publicity. Fifteen pages expressing fear, loneliness and discomfort are tolerable, but an entire autobiography would reveal an unendurable 
lack of control over the events of the past and future. Short fiction and playwriting gained back a sense of control over truth disallowed to the autobiographer's solo document.

At the bottom of the short text, a penciled annotation reads "all awful - saved for reference" (281). Her attempted autobiography does not cut a straight path through description. It is filled with formal arabesques, and skips from theme to theme. Her standards and self-portraiture skills would prevent her finishing the text. The tonal shift between gossip and war is too jarring. For her, it is impossible to mediate good memory and traumatic memory or carefree creativity with the horror of war. She was striving for an impossible balance between historical and personal significance required by her reading public's expectation of accuracy in prose. It took a two-decade struggle to finish The Antiphon to Barnes's satisfaction. The closet drama endured five hundred rewrites before its publication in 1956. Barnes held deep insecurities about what constitutes autobiography outside of her field of expertise: fiction. The Antiphon is an unusual composition, an explosive renunciation, and an "attempt to confess a personal female anger and anguish that was erased by T.S. Eliot's editorial efforts to silence the autobiographical pain that it inscribes" (Alex Goody 339). It is a piece of "traumatic memory" and "performantive witnessing" so embedded in formal lingual experimentation that it defies attempts at normal reading (Goody 340). Its form, that of a drama, requires a theoretical audience, yet it has "deep ambivalence about spectatorial attention" (341). As in Barnes's short-lived Paris war autobiography, she deliberately problematizes the notion of autobiographical account by confounding the reader with antiquated language, complex metaphor and nonnormative storytelling. This is why studying her short fiction in particular allows us to capture Barnes at her most vulnerable, 
at her "surviving" moments outside the Barnes Persona. When she is not loving or abusing her "spectators" and contemporaries as she does in rough draft and play, she presents more self-truth.

Self-judged as “all awful,” we can only judge Barnes's four chapters of autobiography as supportive "notes toward the memoirs," as Herring and Stutman classify it in their title. While it may have been originally intended for publication, it was deliberately scrapped and garners only glimpses of what could have been a deeply complex personal autobiography. If these "notes" cannot be used in isolation to inform an understanding of Barnes's literary persona, a new, careful definition of autobiography must be explored in other available texts.

At this point, an explanation of terminology is in order. "Autobiography" and "life-writing" are not interchangeable terms. Life-writing acts as a larger critical framework and includes the "co-autobiography" label I assign to O'Neal's text. "Coautobiography" in relation to O'Neal's text encompasses a specific life-writing composing subgenre. The life of another person is recorded in real-time and the narrator is witness and participant to that life as it occurs. In "Making, Taking, and Faking Lives: The Ethics of Collaborative Life Writing," G. Thomas Couser calls it the "as-told-to autobiography" or simply "collaborative life-writing". Memories are recalled from the past and observations are made on the present. The future is predicted. In the most basic of definitions, "the writer is one person, but the narrator and subject are someone else" (Couser "Making, Taking, and Faking Lives"). O'Neal plays an active, performative role in Barnes's life for three years. He even determines how events transpire, are interpreted, or excluded from record, up to a point. With a particular text like O'Neal's Life is 
Painful, it is important not to force the composition to fit the definition given. Couser describes this subgenre in terms of contributions, entitlements, roles and balances of power. He theorizes binaries of weak/strong, writer/non-writer, and abled/disabled. The ethical dilemma emerges at the intersection between exploitation, imbalance and manipulation which may sometimes occur between writing partners. O’Neal does not take advantage of Barnes's weakness to produce a biased view of her life. His ethical responsibility to the truth lies in his good intentions. "The ethical difficulties of collaborative autobiography are rooted in its nearly oxymoronic status; the single narrative voice--a simulation by one person of the voice of another--is always in danger of breaking, exposing conflicts of interest that are not present in solo autobiography" (Couser “Making, Taking, and Faking Lives”). The Hank O’Neal - Djuna Barnes writing dynamic is not equal but neither is it entirely exploitative or in a state of chronic imbalance. Is the composition collaborative life-writing if O'Neal and Barnes are alternately weak and strong or manipulated and manipulating in their roles as writers, subjects, and narrators?

A co-authored autobiography or "co-autobiography" is not only a first person account or a biography. Co-autobiography denotes clear collaboration between a subject and the person assisting the production of the subject's story through prose. A collection of conventional co-authored autobiographies are conducted between music journalists and retired performers. The practice of co-authored autobiography is akin to ghostwriting or co-authored biography. The author, subject and narrator of the text are interchangeable, aided in their work by each other. The author's objective is to account for the subject's life in real time. This is no coincidence. During his relationship with 
Barnes, O’Neal was a prominent jazz music producer and writer. Comfortable and curious with reclusive celebrity, his motivations for seeking out Barnes for a coautobiography are equal to the reader's motivations for desiring her story. Barnes's account of herself is not enough. In 1978, the year O'Neal's co-autobiographical record begins, Barnes has not published for over two decades. Her readers want to know who she was in order to reinforce her literary persona and preserve her fame. Her readers want to know what O'Neal may do to "draw her out," and by what reasonable methods he may do it. The act of experiencing, witnessing, recording and publishing a co-autobiography will problematize the notion of authorship.

The boundary between co-autobiography and biography is more important than its boundary with autobiography itself. How can O'Neal's text be classified if the subject of this co-autobiography is drawn into subjectivity unknowingly? During their three year relationship, O'Neal does not reveal to Barnes his intention to use her as a subject of a nonfiction book. During his weekly visits to her home, O’Neal was a confidant errand boy and liaison between her publishers and friends.

It would be unwise to read O'Neal's co-autobiography to the exclusion of observations by other scholars. While O'Neal provides a firsthand account of three years of her life, he does not claim to be her biographer. While his co-autobiography focuses on the long-term results of a lifetime of trauma and her inability to write honestly about herself, Daniela Caselli makes the connection between the content of her short fiction and her experiences with alleged childhood sexual trauma. In Caselli's Improper Modernism: Djuna Barnes’s Bewildering Corpus (2009). Caselli reevaluates the intensity of rumors that implicated Barnes's father and grandmother with sexual assault that may have 
occurred in her childhood. These incidents may have caused her trauma. Despite her experiences, Barnes refuses to create a confessional autobiography or position herself as weak. Caselli writes that "the author omitted from her legacy those papers which she regarded as too personal, resolutely refused throughout the years to produce an autobiography or to comment on those 1920s which she thought ridiculously mystified, and nonetheless took extreme care in amending existing accounts of herself" (Caselli 130-1). Barnes's instinct was to alter verbal and written accounts of her observed life by others, especially when those accounts dealt with her childhood trauma. Barnes's overprotection of her own past and her controlled image and reputation barred critics from connecting her troubled childhood to her secluded old age in a meaningful way. O'Neal's motivation in writing a co-autobiography of her life stems precisely from Barnes's insistence on emending the past. By maintaining her public persona in her writings, Barnes kept a barrier between herself and her own ability to recount her life. Her real existence could not live up to it what she had created.

\section{O’Neal's Autobiographical Truth (Value)}

"Truth" is a philosophical term not limited to autobiographical writings. The importance of true, accurate accounts in O'Neal's co-autobiography must be questioned and classified. As supreme mediator between experience and record, O'Neal is not only biographer, but participant and witness to Barnes's immediate experience. The reader and O'Neal are eager to know the truth of Barnes's seclusion in her Greenwich Village apartment. A pact exists between reader, narrator and writer that defines autobiographical storytelling as a commodity. O'Neal, at least, understands the cultural and monetary 
value of a co-autobiography. If Sidonie Smith and Julia Watson's Reading

Autobiography may guide a classification of terms, the notion of "autobiographical truth" in relation to Barnes's lived experience must change with the telling. This version of truth will always be "the intersubjective exchange between narrator and reader aimed at producing a shared understanding of the meaning of life," and not necessarily an authoritative first-hand account of objective witnessing (Smith and Watson 16-7). The autobiographer is not even an expert on indisputable truth, but must rely on the reader to grant legitimacy. Nevertheless, a co-autobiography cannot be dismissed wholly as inaccurate or useless. The natural unreliability of O'Neal's text may be redeemed by an understanding of the fluidity of truth or truth value. The reader will freely assign significance to the text as genuine testament to performed, personal truth. Margeretta Jolly describes truth value as the "a sense of the necessity of the conjectural and conditional within the auto/biographical enterprise." But O'Neal's text is not equal and opposite to truth itself. His co-autobiography does not need to be automatically de-valued or hidden. O'Neal's involvement in Barnes's daily life only enhances our understanding of her as a writer (Jolly 86-7). Performative witnessing becomes more valuable as a conduit to truth than accuracy of truth "authenticity" or "fact value". In other words, O'Neal's personality and willingness to perform truth value enhances our understanding of Barnes as author of the short fiction studied here.

\section{Themes Present in Barnes's Selected Short Fiction}

Childhood, relationships, pregnancy and marriage are renegotiated as meaningful literary signposts. Barnes also situates fear and fracture in the real. In objects, landscapes, 
relationships, personalities, materials, artifacts, and bodies there are strange powers beyond the use of message or metaphor. Bodies are stained, oily, bleeding, or dusty. Bodies must kneel, crawl, or grovel in the position of rats, horses, or dogs. Her stories uncover themes of death, love, and human existence according to an uncommon, unique and possessive private style of living. Rather than condemn Barnes's bewildering language or seek to clarify it by force, the reader and critic enter into the confusion with a web of connecting themes. In "A Night Among the Horses," a social climbing stableman writhes in the grip of his upper-class lover who means to civilize him. In the final act, he is literally destroyed by the horses he once held an affinity to. In "A Diary of a Dangerous Child," fourteen-year-old Olga is a self-imposed grotesque parody of a child plotting to torture her sister's lover. She is ultimately thwarted by her own recklessness. Barnes's male and female characters struggle between the image and the reality of an image, between human and animal, and between accepting binaries and corrupting or subverting them. "Spillway" and "The Terrorist" situate unsure, doubting female main characters, both silent and speaking, against a history of societal expectations for living that cannot be fully embraced.

Barnes's consciousness is deep and wide. She battles with the self-as-animal and her denial of the notion of the ennobling, contained, and soul-like quality of human consciousness. People are not just bestial and low. Being animal is, to her, a portion of being human. Caselli's understanding of the classical model of selfhood is defined as the body and soul complete and closed off from earthly weight. The body is self-contained and, in essence, whole (Caselli 130-1). The soul elevates the person above the person's world where the body and soul are then one (Caselli 130-1). Barnes invariably drags the 
soul down by realizing the physical body's powers and imperfections and its inherent grotesqueness. Barnes's short fiction also reflects Modernism's fascination with changing perceptions of "human" consciousness separate from past moralities. Her short fiction invariably brings up Caselli's discussion of the "improper" or non-normative Modernism. Shari Benstock admits Barnes's short fictional work "cannot be said to wholly conform to any of these movements of the twentieth century" (233). Barnes holds a unique but central place in the evolution of Modernism, especially as she created a unique vision for herself as a writer.

\section{What is Grotesque?}

The grotesque is a literary descriptive of narratives and characters written outside the narrative norm (Mary Russo 8-9). Hideous or beautiful characters exist under strict, but normal descriptive boundaries. A hideous character may be largely evil and a beautiful one, good. The grotesque character or situation is bound by distortion, transgression and exaggeration of physical features and behavioral traits (Mary Russo 89). These traits can fluctuation in description between comical and alarming. The grotesque occurs in Barnes's short fiction as a combination of material and emotional grotesqueness in which the subject is revealed to act outside usual behavior. Thing-like, animal-like, or simply weighed by overwrought psychological burdens, her characters interact outside normal human feeling and reaction. Her characters have physical descriptions outside normal description. For this reason, the grotesque attempts to engage all the senses at once. Stories of the grotesque contain obsessions with "personal reality" discussed in Mary Russo's theory of the "grotesque realities." Noting the concept of the 
"grotesque body" in Bakhtin's Rabelais and His World, Russo writes that the "the grotesque body is open, protruding, irregular, secreting, multiple, and changing; it is identified with non-official low culture or the carnivalesque, and with social transformation" (8). The short fiction I examine here contains grotesque characters encountering other grotesques in a world of changeable forms and appears to work against normal human behavior and reaction to stimuli. Each story reveals how traits of the grotesque emerge from the normal, and are always already present in the average man or woman.

The grotesque nature of Barnes's short stories reveals the truth behind her state of mind. All Barnes's characters are an impossible, contradictory mix of parts and pleasures, frustrations and freedoms. Transgression, deviancy, guilt, and violence are a means of transition and movement into a dark future. In discerning Barnes's character both as she was writing and into her old age, we must neither uplift nor demote her into a particular category of writer, despite her strangeness. Barnes instilled a possessive grotesqueness through characters on the borderline between normalcy and the unusual or grotesque human. Unlike Butts, whose exploratory occultism disrupts characters' realities and relationships, Barnes's characters navigate the horror of their own failed ideals, the classic or literary ideals of love, recognition, power and personal politics. In "The Terrorists," Pilaat, a self-styled anarchist revolutionary, enacts a grotesque performance of insurrection, rather than its reality. 


\section{Toward a Grotesque-Normal Divide}

"A Night Among the Horses" which appeared in the winter of 1918 in the pages of the Morning Telegraph Sunday Edition, a New York broadsheet. Barnes offered other such stories to newspapers and magazines, including Vanity Fair. Alongside her prolific journalism, plays, interviews and editorials, she wrote fiction targeting magazine readers. At her life's end, she labeled her early pieces as inconsequential. After Nightwood's (1936) publication, all else seemed trivial. A Night Among the Horses (1929) was a compilation of such "trivial" stories. Sun and Moon Press hoped to compile a new collection in 1979 under the title A Night in the Woods, but the threat of public exposure "caused an extended period of despair and rage" in Barnes that ended any book deal (O’Neal 99). Barnes and O’Neal both considered "A Night Among the Horses” and "Spillway" among others written during the same period to be the best of her work ready for insertion in the 1979 anthology. But the act of compiling and choosing works that most represented progressive stages of her writing career threatened a preserved image of herself as self-contained, perfect author. (Warren 99).

In "A Night Among the Horses," John the hostler, obsessed with his upper-class mistress, wonders if he should attempt marriage. Freda Buckler, a small and waifish woman, hopes to civilize John into the cultured world she knows. Throughout the story, John resists such forced transmutations, ultimately escaping Freda's grasp to return to his horses. Unfortunately, in his despair, he is dramatically struck by a stray hoof and is killed. Freda plays grotesque manipulator while John plays helpless victim to her schemes. 
Barnes had participated in her share of Greenwich Village theatricals and must have come across August Strindberg's Miss Julie (1888), either as text or performance (Goody 340). The contextual similarities are striking. In both texts, a low-born servant agonizes over and is elevated by his connection to an aristocratic lady. The boundary between natural and cultural worlds is disturbed; the consequence is always death. John will represent the strange relationship between the natural world and the conditioned, constructed one occupied by his lover. Barnes has "no use for abstractions" in the characters of John or Freda (Caselli 130-1). The two characters cannot help but be physical, material selves. She employs an extraordinary metaphorical precision of observation" much like "a photographic image" but somewhat more authentic (Caselli 130-1). Barnes meant to explore masculinity at its "lowest point" when it has no reference to reputation, social position, or dominance (Caselli 130-1). It contains all the comforts of traditional masculinity as Barnes views it. John is always already in the "halt position of the damned" (Barnes 256). He is neither utter slave to Freda's will to "improve" him, nor satisfied with his lowly position tending her horses. His predicament is now a devil's agreement between receiving help and preserving needed independence. He is perpetually "suspended in a middle state of painful unresolved or incompletion...between the terminal points of his thought and activity" (Barnes 256). Barnes builds waypoints of consciousness here, in which John tears himself from a sphere of alienating wealth. The story's resolution is John's death by horse hoof. He is continually "belied by the essential fact of human instability" right up to the moment of his demise (Louis F. Kannenstine, A Festschrift for Miss Barnes). Beyond Kannenstine's 
reflection and praise of Barnes's skill is a connection to a new kind of materialism or "thing-ness" unknowable to John's own consciousness right before he is killed.

Frost and Coole consider "thing-ness" an historical term "in which materiality is figured not as inert or even passively resistant but as active and energetic" (Kindle Location 593). Barnes's message is a warning against the "essential fact" of the material world, which becomes a swirl of unpredictable, vital forces. Barnes has her characters reject the inherent peace found in the natural world by allowing it to be the agent of John's demise. While Freda revels in the trappings of a luxurious life, John wishes to have both the consequence of wealth and the freedom of personal choice. His death proves a dynamic between reputation and truth is impossible (47-8).

John's conflict becomes a painful mediation between grotesque masculine dominance and grotesque feminine submission. His role as free-willed, masculine agent is manipulated by Freda in order to make him a partner worthy of her personal lifestyle. This lifestyle becomes a new form of distorted, grotesque masculinity without genuine feeling. At the whim of a complex, active engagement in the "forces and flows" an untamed natural world, John is now debased. His control of animals and women alter and twist away. He is made low. He crawls on hands and knees through the horses' pasture. He "peered through the thickly tangled branches and saw, standing against the darkness, a grove of white birch shimmering like teeth in a skull" (247). Later, Freda binds his hands, snaps at his legs, forces him into constricting costumes; but ultimately, she cannot change his character. The metaphor of man-as-horse, as debased animal, emerges from this forced transformation. An effort to civilize and domesticate John only separates him further from his humanity. She even tortures him with the privilege of moneyed 
education he will never obtain. Objects and artifacts shown to John by Freda become the barrier between knowledge and ignorance. The intersection between becoming a "real" man and becoming an animal is problematized in the face of ostentatious wealth. Freda Buckler is "the mistress of the house," and "a small fiery woman, with a battery for a heart and the body of a toy... who purred saturated with impudence, with a mechanical buzz that ticked away her humanity" (249). The further Freda is mechanized, the further John is made animal. The final outrage comes as John is meant to be a showpiece costumed as a horse-handler at a large party. He becomes an irrational, almost ridiculous, base, thing-like nonbeing (Alex Goody 56-60). The boundaries between a loving relationship and a manipulative one become increasingly blurred across class lines.

Freda then takes on a cartoonish version of masculinity while John still hopes to marry her. John treats her wealthy existence as separate from the natural world he inhabits, despite his attraction to her. He loves her, but considers her world distasteful, decadent, alienating, and manipulative. Before he can mediate the differences between Freda, himself and the natural world, he is struck and killed instantly by a startled horse. Freda's cruel inhumanity is the antithesis of traditional womanhood. Femininity is then crystallized, turned cold and separate from the conventional masculinities defining it before John's entrance. Only women such as Freda have access to modes of becoming and agency. Her wealth and education allow her special reward. Her mutated femininity follows no natural progression. Freda's persona is a "mutation which creates a disturbance in the hierarchical and monological ordering of culture and gender" defined only by its method of destruction (Goody 158). The presence of the horse-body in the narrative dissolves old interpretations of sexual difference held by John and Freda. The 
material body becomes a force in its own right. It is capable of its own destruction and the destruction of other bodies. John's body is the witnessed, "the grotesque body" which is always "open, protruding, irregular, secreting, multiple and changing" (Russo 8).

Barnes fashioned a new term to describe such manhood: the masculine grotesque. "A Night Among the Horses" does not reveal exactly how the masculine body is associated with the natural world or whether it succumbs to a final transformation into an animal. The consequences of this transformation from natural being to purely social being is ultimately destructive, especially across blurred class lines. While John considers marrying Freda, the desire for love tears away at any psychological stability he once held. The normal boundaries of loving relationships are fragile and contested, thus "creating mutation out of potential relations" (Alex Goody 151). The traditional hierarchy of gender and class still holds sway over the potentially transgressive relationships across class. Freda herself is a mutation or corruption of the pillars of domestic womanhood. Her feminine domesticity is associated "not only with material reality but also with the horse/animal imagery that pervades the story" (Plumb 56). She sits at the boundary between being the material body and the image of the body. Grotesqueness lies in physical description, but Freda's character is also an image and a fantasy. Barnes's descriptions contain no abstractions; only physical and tactile sensation. She is depicted “stroking [John's] arm, throwing her head back, her nostrils scarlet to the pit...a boot's length apart, she no bigger than a bee on a bonnet" (Barnes 249). While her body is small and "bee-like," John is seen as "horse-like" and yet submissive to Freda's personality in all respects. 
The story begins and ends with an image of John crouching near the pastures of the Freda Buckler manor-estate. John cowers in the tall grass, both wanting to rejoin his animals and escape social overstimulation from a party. Barnes allows the grotesque body to be a point of departure for John. When the horses finally reared up in fear over his sudden appearance, "manes up, nostrils flaring, blasting out steam," they "passed him in a whinnying flood, and he damned them in horror, but what he shouted was "Bitch!," and found himself swallowing fire from his heart, lying on his face, sobbing” (254-5). Freda's insect-like androgyny and cruelty cause John to experience what Louis F. Kannenstine calls "the pure fact of death" (A Festschrift for Miss Barnes, ed. Alex Gildzen). Cheryl Plumb even notes Barnes never focuses on "the nature of death - its deceit, or unfairness, or its release...death is a fact that motivates the need for conscious living rather than evasion (57). Its presence is the essential condition of human existence. John realizes, in the moments before his death, the impossibility of living in two worlds: the world of nature and the world of culture. The corporeal, low, earthy body is always present and always consuming. The social world is an alien one. John literally crawls through the underbrush like an animal to escape that world. Barnes presents us with a modern world growing strange, in which the transitory pervades. In Barnes' Consuming Fictions, Plumb's succinct explanation of John's actions exposes a strange divide: Barnes "questions the basic human motivation to make a mark, to achieve something. That effort appears futile in the world of nature, which is hostile or at best indifferent to man and [in] which human consciousness perceives man as apart from nature - yet equally futile is the material and limited social world of Freda Buckler..."(Barnes 57). 
In Frost and Coole's New Materialisms, the phenomenon of disorientation is described as "the active process of materialization," in which "embodied humans are an integral part, rather than the monotonous repetitions of dead matter from which human subjects are apart" (8). Human-made abstractions such as ambition, reputation, hostility and even love are inextricably linked to the material world. Death itself has its own materiality proven by Barnes's interpretation of the natural world as interactive force rather than inert matter. The natural world has the ability to cause death, suffering, and indifference. The boundary between "civilized" and "animal" and its binary relationship between grotesque and real in the fantastical space of the story is still mutating.

Ultimately, Barnes pulls for no hero. Her prose is "contradictory and ambitious," forming "abrupt and truncated conclusions" (Plumb 56). The reader is made to "explore the limitations of material existence and the response of the superior sensibility" (Plumb 56).

Freda is described as "the kind of woman who can't tell the truth; truth ran out and away from her as though her veins wore pipettes, stuck in by the devil; and drinking, he swelled, and pride had him" (250). Freda has the sleek, shelled body of an insect, a "praying mantis" (Barnes 250). But she is also the gatekeeper to high culture, tormenting John with the possession of beautiful things. While expensive artifacts are signs of culture and wealth, nature is a sign of violence, blood, and lowly growth. After seeing such artifacts, John vows to "make his mark on the world" without the powerful, decadent culture of his lover. Toward the end of the story, Freda makes a clear distinction between her own social position and John's position. She "asked him to hold ancient missals, volumes of fairy tales, all with handsome tooling, all bound in corded russet. She spread maps, and with a long hatpin dragging across mountains and ditches, pointed to 
'just where she had been" (251). Freda has ownership of fine material art objects and the knowledge those objects represent. She acts as gatekeeper to culture, barring and then taunting John with perceived persona of worthiness and culture. The ownership and display of the aforementioned "handsome things" can have civilizing effects. Material possession forces John to wonder at what he cannot comprehend. Freda's love, too, is meant to civilize. But Freda's inhuman and grotesque distortion of love only drives John further into the "uncivilized" or undomesticated, impersonal natural world. The two worlds cannot blend or support each other. In the end, John realizes "he wouldn't fit inanywhere after Freda, he'd be neither what he was nor what he had been" (251). The riddle of identity will never be solved.

\section{The Grotesque Body in Illness, Marriage and Death.}

Another tale of corrupted relationships appears in "Spillway," the first tale published in the revised and collated Spillway (1962). In the second story, the guilty female body has escaped punishment for adultery by recovering from a terminal illness. "Spillway" has a simple premise. Returning to her country home after a five year hiatus recovering from what she names, "the white death," or lung cancer, wife Julie Anspatcher brings her young, illegitimate daughter to meet her husband, Paytor for the first time.

While Julie has misgivings about returning to her estranged husband, she arrives with the hope of a positive reunion.

Barnes ties Julia's conception, pregnancy and lung cancer into the same philosophic knot of guilt over an escaped fate. Julia labels her adultery a self-imposed sickness or disorder from which she is now recovered. She tells her husband she feels 
alienated from her body, almost to the point of total disassociation. She does not feel conventional regret or horror at having betrayed her husband or the sanctity of marriage. Giving birth emerges as deviant, rebellious female behavior. She admits to Paytor: "No I don't feel horror - horror must include conflict and I have none; I am alien to life, I am lost in still water" (273). Convention horror stems from a horror of natural deterioration and of refusing to receive absolution from a religion she cannot believe in. Julia's enemy is her own guilt for committing adultery and surviving cancer simultaneously. Her conflict is neither established by her husband nor marriage, but simply the horror of natural, impending death, even after one has forgiven mistakes and escaped a terminal illness. Even Catholicism cannot offer her forgiveness. Julie notes, "I've tried to believe in something external and enveloping, to carry me away, beyond - that's what we demand of our faiths isn't it? It won't do, I lose it; I come back again to the idea that there is something more fitting than release" (273). When Julia uses the word "release" she confronts her own guilt at having abandoned her husband. Death could release her from the burden of sinful adultery but facing her choice has kept her in the reality of marriage. Julia cannot invest herself in the rhetoric of Catholicism, which gives absolution to worshippers during confession. Her shame in leaving her husband, having a child out of wedlock and renouncing religion entirely only makes the idea of faith impossible to her. She notes again, "I don't feel divided; I seem to be a sane and balanced whole, but hopelessly estranged" (274). She can neither bring herself back to the abstract beauty of faith-based forgiveness nor is she entirely consumed by guilt or conflicted in her choices. Barnes's character explores the spiritual and material manifestation of guilt 
felt in the absence of feeling guilty. One can, by turns, feel guilty when one realizes one has not felt it for so long.

Julia feels no conventional guilt, nor is she punished by outside forces. Her husband accepts her eagerly back in marriage. She suffers through "dualities of existence," between blame and forgiveness (Kannenstine A Festschrift for Miss Barnes). Kannenstine insists she "must either suffer without comprehending or collapse under an intolerable burden of understanding. The essence of the whole work, then, is enigma" (Kannenstine A Festschrift for Miss Barnes). There is a mysterious inner conflict or discord between materiality and spirituality in Barnes's short fiction. Julia must reject the concept of forgiveness altogether. She is neither qualified nor stable enough to receive forgiveness from herself or her husband. Religion, too, has a materiality undefinable by Julia's mind alone. Though she recovered once from illness, death is still inevitable despite one's health. Coole and Froste attempt to mediate materiality with "a tiered ontology" in which there is "no definite break between sentient and non-sentient entities (the thinking human and the house she occupies), or between material and spiritual phenomena" (10). The "natural environment is far more complex, unstable, fragile and interactive than earlier models allow" (13). Julia embraces the traditional Catholic concept of penance in order to "materialize" her grief and regret. "I've been on my knees, I've beaten my head against the ground, I've abased myself, but...it is not low enough, the ground is not low enough; to bend down is not enough, to beg forgiveness is not enough; to receive? - it would not be enough" (271). Even the abstract forgiveness of God is not enough to change her idea of personal guilt so that she may revert to a period of domestic normalcy. 
Barnes's ultimate message stems from the title, "Spillway." A spillway is an opening or valve for flood water to exit the walls of a dam. To Julie, water is also a tangible object. It exists in different spatial planes. It can also be held and poured. Water itself changes, ripples, flows, tastes and smells differently during separate moods or perceptions. Julia becomes, in her final scene, another complex contradiction of Barnes's imagination; a woman unsure of her place in the world. She exists across a strange spectrum of moralities. Julia is neither entirely regretful nor particularly proud of her actions, but exists somewhere in an amoral middle. At one moment, she may control her life like a hand cupping water: "Water in the hand has no voice, but it really roars coming over the falls. It sings over small stones in brooks, but it only tastes of water when it's caught, struggling and running away in the hands" (Barnes 275). The same water is distorted, guided, and made abstract by the unfairness of facing death. She can neither accept the inevitability of death nor totally reject it. Her husband's forgiveness after her five year hiatus is proof of a grave conflict between wanting to die of shame and almost dying of disease. She notes, again, “There just isn't the right kind of misery in the world for me to suffer, nor the right kind of pity for you to feel; there isn't a word in the world to heal me; penance cannot undo me - it is a thing beyond the end of everything - it is suffering without consummation" (271).

Barnes's perspective on the nature of suffering is presented in O'Neal's coautobiography. While Barnes is not a direct substitution for the main character herself, she knows suffering and depression must exist in that same main character. No human or religious effort to "save" her is possible. "Mortality itself" or "life itself" is always already present in the human, despite what she might feel about her situation. The ending 
deploys the reader into a self-tortured subconscious. Julie's husband, Paytor, commits suicide. Grimly, life can never be a "choice between pastoral simplicity and social values...Rather the abrupt ending implies that mortality itself is the limiting factor of life," (57).

\section{The Social, Grotesque Body and Violence}

"The Terrorist" is one of Barnes's earliest published stories is in the New York Morning Telegraph Sunday Magazine September 30, 1917. Contemporary connotations aside, "terrorism" in 1917 was a complex series of movements sweeping the United States and Europe. The 19th century saw the emergence of "anarchist terrorism," a set of philosophies primed to aid the struggle of working class Industrial Age peoples by means of violence, assassinations and bombings. The "propaganda of the deed," a political slogan inciting anarchists to exemplary behavior, was a self-serious philosophy rationalizing communal violence (TPD Dugdale-Pointon "Propaganda of the Deed"). Barnes must have been confronted by news headlines warning of Russia's October Revolution of 1917, which occurred two months after the story's publication. Barnes deconstructs what she believed was a pompous, empty form of political and social upheaval by laying it in the hands of violent, yet incompetent characters. The story revolves around Pilaat Korb, an ex-revolutionary, and his unnamed wife living in an apartment building in a mid-sized village. After a day of heavy drinking, Pilaat and his friends plot to launch anarchy and murder in town as an act of protest against a vaguely realized fear of conformity and oppression. After the story's leisurely description of his wizened body and idiosyncratic behavior, its subtle power lies in the description of the 
character of Pilaat's silent wife. Barnes writes, "She liked to be the center of whispers, for then she could be impersonal and forget herself without any danger of falling into obscurity" (186). She also "did not like the society of silly and vain women, and she did turn most naturally to such men as her husband moved among" (189-90). Pilaat, on the other hand, is irreverent. His intent to cause mayhem in the town is a satire of both revolutionary behavior and the power of masculine bodies to make change.

Also, both Pilaat and his wife are described in wholly physical terms. They eat, drink, and wear soiled clothing. Pilaat's young wife is missing teeth and has sallow skin. Pilaat is also known for his vigorous digestion. His eyes excrete water. He is soon consumed by his strange, complex, and distorted grotesque idea of how humans should behave in the world. Pilaat's massive apartment building is describe as "a woman who had fallen from wealth and distinction and esteem, who had lost all her admirers, but not quite all her looks - a silk and beribboned petticoat hidden by a calico dressing gown, a torn stocking thrust into small and delightfully fashioned slippers, a well-appointed mouth closing on crumbs" (188). Pilaat and his wife are similarity clothed. The characters embody ideals remarkable modern in theory and old-fashioned in real-time performance. Pilaat and his wife put personal pleasure over the mission to commit murder and anarchy. Barnes assigns "anarchy" as morality. She ridicules it as an inherently selfish and ineffectual ideology.

Barnes is eager to ridicule the concept of "born the terrorist," a term absent of modern connotation, and turns the fearful terrorists figure into a fantasy of impotent anarchy. Barnes is quick to stress Pilaat's lack of humanity and the petty, confrontational attitude he uses to deal with his fellow tenants. "Those who knew him longest made the 
mistake of calling him "more like a human being"; and those who knew him the least made the correct judgment, that he was "drinking too much" (184). Barnes is eager to turn a serious and historical sense of the revolutionary into a lifeless parody incapable of carrying out the murder it espouses. The revolution, she notes, is a grotesque and useless concept in which the physical world trumps the metaphorical. Terrorism cannot escape into principle and self-importance as it deals death by claiming a higher morality through the sanctity of violence. Pilaat Korb imagines a world of anarchy in which the realm of order, closure, and rationality is smashed away by restless violence, change, and transgression. When human life is tied to a political cause, it is still weighted by a need for food, clothing, and desires for luxury goods. Pilaat's wife worships her husband, not for his terrorist principles, but because he appears to be feared by his friends.

Objects, too, play a key role in the story's meaning. Like Freda, Pilaat's wife has a strange relationship with what she desires in the material world. She carries with her none of the conventions of femininity, and offers no explanation for her distanced behavior or her lack of political commitment. She continues to position herself outside the hierarchy of culture and gender. In addition, Pilaat's distorted concept of "a revolutionary idea" is weighed down by his objectification of community leaders and his own animalization. He announces, "In the dawn we shall do it. In the dawn we shall creep forth to make the world better for men. They will see us coming, creeping on all fours, - and they will say, 'Here are the rats.' They shall learn what rats can do" (Barnes 195). But Pilaat's wife remains passive throughout the entire story. She neither confirms nor rejects her intent to commit murder, perhaps because she knows her husband's group is incapable of committing it. Terrorism is tied forever to the physical world, no matter 
how it may self-aggrandize. It could be parody of the performance of rationalizing the ridiculous.

At the story's end, Pilaat is asleep. His wife awakes, and walks over the bodies of her guests: "All of them, in their sleep, had moved away from those things that they had collected as weapons. They had rolled onto them, and they found that they hurt and were uncomfortable... She thought of her favorite cafe, and she smiled as she contemplated one or two new phrases she would use in relation to life" (195-6). Terrorist acts are reduced to a slogan, a catchphrase, or a book of bad poetry. The threat to kill dissolves in the morning. In another way the grotesque, terrorizing body is preoccupied with the space of risk and abjection without having the body perform its murderous follow-through. Pilaat and his wife are largely ineffectual in their intent to make change, to assert their will over each other or the hated world. They both continue to degenerate further into alcoholism, self-doubt and amoral ambiguity, even as they struggle towards the opposite can-do philosophy of total anarchy. To Barnes, even the incantations of the sociopolitical firebrand are a thorough mockery.

\section{Grotesqueness in Normative Girlhood}

"The Diary of a Dangerous Child," is a light-hearted magazine fiction piece. It appeared in the July 1922 edition of Vanity Fair and appeared again in A Night Among the Horses, published only a few years later. This particular magazine story had a witty byline: “...Which Should Be of Interest to All Those Who Want to Know How Women Get the Way they Are". It functions as a pseudo-cautionary tale for popular readers of Vanity Fair. 
A fourteen year-old girl, Olga, living with her mother, father and uncle in a middle class home composes what she considers diary entries in the first person. These diary entries are entirely fabricated for the purposes of narrative, but in the reality of Olga's experience they act as medium between her uninhibited girl-consciousness and the presumably grown-up reader. Don Passos Dilemma is a foreign suitor to Olga's sister. His constant presence in the house infuriates Olga who calmly plots a way to lure him away from her sister in order to beat him with a riding crop. Any terrible action beyond the point of complete execution does not occur to her youthful mind. Olga ponders the nature of womanhood and her emerging role as woman. But, her plot having been foiled, her mother sabotages her trap for Dilemma, punishing Olga with strict home confinement. Olga ends her musings with utter bitterness toward all gender formations, including her own.

At the beginning, Olga notes, "I am debating with myself whether I shall place myself in some good man's hands and become a mother, or if I shall become wanton and go out in the world and make a place for myself" (Barnes 227). She plays neither the role of the obedient child nor the willful adventuress. "The Diary of a Dangerous Child" shares with [Barnes's other stories] a light-heartedness to which it would not be difficult to a cast-off...[it] explores the limit between innocent natural child and gendered "nonchild... she is placed on the threshold between childhood and womanhood" (Caselli 145). The concept of the "non-child" is disturbing. Precocity in a child is used to explain erratic, but still endearing behaviors for girls. Olga, who is, according to Casselli, a "nonchild," plots to wreak havoc on the family sphere by attacking an adult man. The nonchild is neither child nor adult. She claims for herself properties of both girlhood and 
womanhood with embodying either. Danger, violence and agency awarded to an adult woman attach itself to the naiveté of a child. Caselli connects it to the "precocious child" popular in magazine fiction (122). The child Olga recognizes and resists conventional rules of adulthood and speaks satirically about the nature of her own future womanhood. Vanity Fair tales were meant to entertain, shock, and satirize childhood itself. A "normally good" child does not exist. It becomes impossible to characterize the erratic, violent, inexplicable behaviors of girl-children who do not conform to a normative view of potential womanhood. Her evolution from girl to woman is stunted by non-normative childhood behaviors.

"A Diary of a Dangerous Child" also straddles the line between literature and popular magazine prose. Wexler's concept of the "Modernist solution to the dilemma of art as commodity" is present here (Wexler 123). Barnes uses "complex [literary] forms that seemed accessible to many readers as a way to demonstrate indifference to money and devotion to her art" (Wexler 123). When Barnes spoke of a deep devotion to art to O'Neal in the 1970s, she brushed aside the importance of such tales; they were written for survival. A “child's diary" genre was particularly suited to a magazine's need for personal confession and girlhood adventure. It is a willful carnivalesque, in which transgression may occur only within the space of one day (Caselli 145) and not beyond it: "While the genre of the diary seems to promise access to the child's mind, it also constructs the child as secretive: the child's outpourings are also dangerously nonspontaneous, indirect, untrustworthy, and ultimately un-childlike" (Caselli 145). Here, again, Caselli proves Olga is not satisfied with her role now. Olga's dissatisfaction is reflected in the diary medium. Olga's version of confessional and fantasy finds its 
framework in a child's version of a diary, a composing genre distorted by her own undeveloped emotional being. Barnes corrupts the traditional view of "childhood" through this diary. Olga is conniving, dishonest and selfish but also "standing between life and death," and "any moment might have been [Olga]...One's mind is said to go back over every detail, she says, anyway mine went back" (333). The child is also a construct, "a figure of impossible simplicity" but also "a melancholic mediation on the construction of sexuality and linguistic innocence" before adulthood (Caselli 150). As Caselli later notes, the theme of the deviant "child-woman" repeats itself in Barnes's later work, especially in Ladies Almanack. Despite Olga's ultimate punishment by her mother, she escapes the consequences of attempting to beat Don Passos Dilemma. She is left with her "own transcendent nature" (332). Rather than become a virago or wife, she decides to "run away and become a boy" (334). True predictive speech is less important than Olga's sense that her proposed events will come to pass.

In this story, Barnes uses conventions of the diary genre with flighty imagination. While the diary of a dangerous child is unpredictable and haphazard in its preoccupations, it moves tonally forward with the force of a child's mind (Smith and Watson 266). In theory, Olga's diary is not meant for public consumption, appearing as a scandalous document in a weekly newspaper. Barnes's characterization of Olga acts as intermediary between secrecy and exposure and between girlhood and womanhood. Where a normative girl's diary may be uneventful and tame, Olga's diary is consumed by adult transgression and violence open to the judgments of public readership. 


\section{O’Neal Seeks Truth Value in Barnes's Life}

While O'Neal's co-autobiography calls for a reevaluation of Barnes's life, and offers clear, eye-witness accounts of her daily thoughts, it cannot be treated entirely as if Barnes herself was writing alone. Compare The Antiphon, Ladies Almanac, or her autobiographical rough drafts to Life is Painful. Barnes spent years expressing traumatic personal history through her fiction. O'Neal's Life is Painful was researched and composed without her knowledge and published after her death. Yet, it is a more useful co-autobiographical account of her life than anything she herself was emotionally capable of producing. She is participant, though not director, of three years of her own life. "Most of the wording of the final text is attributable to the "writer,"...partners' contributions are not only different, but incommensurate, entities--on the one hand, lived experience mediated by memory; on the other, the labor of eliciting, recording, inscribing, and organizing this material" (Couser "Making, Taking, and Faking Lives"). The narrative is formed and maintained by O'Neal's "personal assistant" role in Barnes's life. His ultimate responsibility is enhancing our understanding of Barnes's declining years through his relationship with her as co-autobiographer, friend and helper.

But, as the co-autobiography progresses, O'Neal's once naïve relationship with Barnes turns strained and scornful. He begins to question his accountability in stabilizing her life. After a long absence, O'Neal returns to an agitated Barnes, who, in her frustration, accuses O'Neal of manipulation and stealing. Two hundred pages of coautobiography do little to prove her case against him, but O’Neal calmly remarks it may have been the final deterioration of Barnes's psyche. The pain of dependence and supportive friendship had shattered her self-image. He writes "nothing made any 
difference in the end as she raged helplessly against her own creation. She'd created an aura about herself, made herself mysterious, and lived a secluded life to protect her creation....she had created her own world with her own values: she was the centerpiece...she was unable to stop the process as it slowly reached its inevitable conclusion" (194).

Hank O’Neal met with Barnes every day for four years, acting as her secretary, confident, executer and listening companion. O'Neal believed Barnes's life was padlocked to her writing. A depressed, aging Djuna meant depressing poetry. In 1979, O'Neal sorted drafts in Barnes's apartment containing snippets of poems and stories. $\mathrm{He}$ lists his finds as "repetitive, brutal and horrifying" (88-9). Barnes begins a fragmented poem, "The maggots fasten on her breastbone's meat," "Death doth make her sing," and "Death is her King...Charge her walking mort...she scalds her bush with blood. I buzz the gate" (88-9). O'Neal writes: "I read on and on, hoping to find a bit of cheer somewhere, but it was not to be found in her work of the past forty years...It was no wonder her outlook on life was so totally dismal" (89). Barnes's deep self-criticism prevented her from remembering her short fiction with fondness; the feeling may even have prevented her from writing more than one well-known novel.

O'Neal is eager to present "her reality," and to present himself as an impassioned, but still unbiased, stenographer of "a vigorous mind partially overcome[ing] the infirmities of old age" (3). He claims to have no emotional investment in her writings (3). He has not read them. He presents himself as wholly objective and completely separate from the gossipy yellow journalism from past decades. But it is precisely Barnes selfremoval from the realm of opinion, the realm of "Miss Barnes," that makes him a self- 
claimed arbiter of truth value, and therefore, a lens through which Barnes's "reality" must filter. O'Neal continues by noting "this is what she said to me, what she presumably believed, and/or what she apparently wanted me to believe....It was how she remembered the past, her personal reality..." (O'Neal 3). It is only through the power of O'Neal's perception of her personality reality can Barnes's true personality shine. Barnes's reality, no matter how chaotic, filters through the perception of another, for good or evil. O'Neal writes "the remembrances in the autobiography that follows tell a good deal about Barnes, the ideas she expressed, how she remembered events of the past and her contemporaries, what she thought of the world around her, and how she viewed herself" (O’Neal 2-3). He admits "the originals were done hurriedly...I have retained items I know now to be inaccurate, and my most naïve impressions, simply to retain a sense of how the relationship developed" (O'Neal 2-3). The co-autobiography becomes a series of impressions about an intimate relationship rather than a factual record of her life, even as he insists on its truth value. Inaccuracies are then embraced as part of the process of daily observation. O'Neal believes the reader should be satisfied with his own method of composition and recordkeeping. This satisfaction stems from a more complete understanding of O'Neal's positive presence in Barnes's life, even as their relationship soured by unmet needs. Again, the reader, narrator and subject ideally would have formed a pact of understanding that allows autobiographical truth to have its own value.

Barnes did have a motivation to publish beyond that of creative expression of her life's themes. Many short pieces were published between 1915 and 1925. Not all of them are as decipherable as the four studied here. She published much of it under the necessity of earning a living for herself and her family. Unfortunately, at the end, Barnes did not 
cherish her short tales as she did Nightwood or The Antiphon. Barnes had ruthlessly pared down what she deemed "publishable" stories from fifteen to eight. Unauthorized publishing of such stories infuriated her. She also admitted to despising the stories she wrote for money (Plumb 55-57, Diane Warren 99). Her short fiction was a reminder of past poverty and a commercial need to tailor her art to public taste before she had made a name for herself. Along with her grandmother, she supported several neglected siblings in the wake of an absent father. Sun and Moon Press published Spillway, a collection of her "best of her short fiction" in 1962 (O'Neal 134). It was only in 1977, furious with the unauthorized republication of Spillway, that she was ashamed of her short fiction's commercial appeal. But there may be some genius behind a careful mixing of commercial and literary success. Her short fiction is not necessarily equal and opposite to Nightwood, which was, to O'Neal, not "widely palatable" (134). She attempted to mediate a need for money with the personal expression of a complex mind. In Who Paid for Modernism? Joyce Piell Wexler deftly explores the rift between high art and the mechanism of pubic literary consumption. She argues that writers like Djuna Barnes, D.H. Lawrence and James Joyce tailored their literary styles and subjects to their own expression and to the exclusivity of reading taste. But exclusivity could not last. In the last section, "Why Art Pays," she writes, "Highbrow writers could not accept sales as an index of literary value...contempt for money became the defining feature of the serious artists, yet earning money was essential to maintain one's professional status" (Wexler 124).

Through this publishing tactic, and her wealthy patron, Barnes preserved her aesthetic in magazine short fiction, despite a dire need for cash. While other Modernist writers struggled to remain popular, Barnes sustained her accessibility, at least, in her 
short pieces. Wexler then writes, "The Modernist solution...was to use complex forms that seemed inaccessible to many readers as a way to demonstrate indifference to money and devotion to art. Since it was also necessary to earn a living by writing, however, Modernists cultivated patrons and readers by generating publicity in the popular press" (124-9). Especially in such stories as "The Terrorists" and "The Diary of a Dangerous Child," Barnes was hoping to preserve her personal aesthetic without pandering to a lowbrow audience.

\section{Unification and Inclusion of Barnes's Short Fiction}

In the human's hour of need, the force of nature is no longer tamed by the convention of needfulness. The world is no longer, or indeed, has never been, in the service of humanity. It has sudden, visceral reactions to the human's negotiation with it. I have now examined three revolving nodes of meaning in Barnes's life, persona, and fiction. Barnes was consumed by a self-enforced image of aloofness, of a genius without flaw or feeling. Through a new discovery of the grotesque in man, woman, and child, her estranged image may be reevaluated. The grotesque can be found inside normativity. Hank O'Neal's co-autobiography, incomplete as it is, allows us to read personal truth value behind the Barnes Persona he attempted to bring to light. Djuna Barnes wanted to show the uniquely grotesque inside the normal body; she wanted to show us that an inherent grotesqueness defying repulsion encountered from "normal" perspectives. When we begin to use Smith, Watson and Couser's framework of justice and ethics, we may connect Barnes's short fiction to the fragmented autobiographical record to understand how her methods for living clashed with her methods for making art. "The justice of the 
portrayal has to do with whether the text represents its subject the way the subject would like to be represented," notes Couser, "with whether that portrayal is in the subject's best interests... and with the degree and kind of harm done by any misrepresentation" ("Making, Taking, and Faking Lives") Instead of portraying O'Neal as heartless manipulator, his flawed understanding of Barnes allows a clearer glimpse into the ultimate message of her work as "purely personal" (Andrew Field 10).

Barnes's short fiction reveals women's writing as not quite designed for certain readers, but transgressive, rebellious and adaptive to changing audiences' tastes and rejections. Ultimately, Barnes has accomplished a strange hybridization of Modernism unseen in other writers. On the last pages of A Festschrift for Djuna Barnes on her $80^{\text {th }}$ Birthday, Kannenstine writes "the women that pass through The Book of Repulsive Women in awful haste are perceived in their dual state of damnation and innocence. Women are seen as 'repulsive' or denatured. Women are neither animal nor fully human, but caught in a continuous and unstable process of becoming." But also Barnes "lessened the distance between ape and angel, between the material and spiritual, between the thing and the soul. Living, she continuously implies, is being never utterly damned nor wholly transfigured, but tending at any moment toward the two conditions" (Kannenstine). Barnes has contributed, through her O'Neal-revealed "true" personality and the grotesque-inside-the-normal present in her fictions, to a hybrid Modernism. If an intertextual splice can be made in the stem of Modernist fiction, women's fiction and grotesque fictions, its presence may alter the species' future altogether.

At this point, it is important to move toward an inclusive Modernism by way of Barnes and Butts. Even though Barnes and Butts are not well-known Modernist writers, it 
is important not to forget their contributions to an inclusive Modernism. While high Modernism is "filled with the economy of scarcity and purity," Barnes's and Butts's brand of Modernism assigns value to the low, the animal and the grotesque within the "purity" of normal human interaction (Wexler 125). With the aid of available life-writing, Barnes's and Butts's short fiction will gain new meaning, new importance, and shed further light on the larger, more well-known works enjoyed by readers. 


\section{REFERENCES}

Alaimo, Stacy, and Susan J. Hekman. Material Feminisms. Bloomington, IN: Indiana UP, 2008. Print.

Bal, Mieke. Narratology: Introduction to the Theory of Narrative. Toronto: University of Toronto, 1997. Print.

Barad, Karen Michelle. Meeting the Universe Halfway: Quantum Physics and the Entanglement of Matter and Meaning. London: Duke UP, 2007. Kindle.

Barnes, Djuna and Emily Holmes Coleman and G.C. Guirl-Stearley. "The Letters of Djuna Barnes and Emily Holmes Coleman (1935-1936)." The Missouri Review 22.3 (1999): 105-146. Project MUSE. Web. 18 Jan. 2015. <http://muse.jhu.edu/>.

Barnes, Djuna, Alyce Barry, and Douglas Messerli. Interviews. Washington, D.C.: Sun \& Moon, 1985. Print.

Barnes, Djuna, Phillip F. Herring, and Osias Stutman. Collected Poems: With Notes toward the Memoirs. Madison: University of Wisconsin, 2005. Print.

Barnes, Djuna. Collected Stories. Los Angeles: Sun \& Moon, 1997. Print.

Barnes, Djuna. The Book of Repulsive Women: 8 Rhythms and 5 Drawings. Los Angeles, CA: Sun \& Moon, 1994. Print.

Benstock, Shari. Women of the Left Bank: Paris, 1900-1940. Austin: University of Texas, 1986. Print.

Butts, Mary, and Nathalie Blondel. The Journals of Mary Butts. New Haven: Yale UP, 2002. Kindle.

Butts, Mary. From Altar to Chimney-piece: Selected Stories. Kingston, NY: McPherson \&, 1995. Print.

Caselli, Daniela. Improper Modernism: Djuna Barnes's Bewildering Corpus. Farnham, England: Ashgate, 2009. Print.

Coole, Diana H., and Samantha Frost. New Materialisms: Ontology, Agency, and Politics. Durham [NC: Duke UP, 2010. Kindle. 
Couser, G. Thomas. "Making, Taking, And Faking Lives: The Ethics Of Collaborative Life Writing." Style 32.2 (1998): 334. Web.

Dugdale-Pointon, TDP. (28 May 2001), Propaganda of the Deed, http://www.historyofwar.org/articles/concepts deed.html. Web.

Faltejskova, Monika. Djuna Barnes, T.S. Eliot and the Gender Dynamics of Modernism: Tracing Nightwood. New York: Routledge, 2010. Print.

Field, Andrew. Djuna, the Life and Times of Djuna Barnes. New York: Putnam, 1983. Print.

Fitch, Noel Riley. Sylvia Beach and the Lost Generation: A History of Literary Paris in the Twenties and Thirties. New York: Norton, 1983. Print.

Fludernik, Monika. Towards a "natural" Narratology. London: Routledge, 1996. Print.

Ford, Hugh D. Published in Paris: A Literary Chronicle of Paris in the 1920s and 1930s. New York: Collier, 1988. Print.

Foy, Roslyn Reso. Ritual, Myth, and Mysticism in the Work of Mary Butts: Between Feminism and Modernism. Fayetteville: University of Arkansas, 2000. Print.

Frost, Laura Catherine. The Problem with Pleasure: Modernism and Its Discontents. New York: Columbia UP, 2013. Print.

Gan, Wendy. Women, Privacy and Modernity in Early Twentieth-century British Writing. Basingstoke [England: Palgrave Macmillan, 2009. Print.

Gilbert, Sandra M., and Susan Gubar. Feminist Literary Theory and Criticism: A Norton Reader. New York: W.W. Norton, 2007. Print.

Goodspeed-Chadwick, Julie. Modernist Women Writers and War: Trauma and the Female Body in Djuna Barnes, H.D., and Gertrude Stein. Baton Rouge: Louisiana State UP, 2011. Print.

Goody, Alex. "“High and Aloof": Verse, Violence, and the Audience in Djuna Barnes's The Antiphon." Modern Drama 57.3 (2014): 339-363. Project MUSE.

Goody, Alex. Modernist Articulations: A Cultural Study of Djuna Barnes, Mina Loy and Gertrude Stein. Basingstoke [England: Palgrave Macmillan, 2007. Print.

Gray, Nancy. Language Unbound: On Experimental Writing by Women. Urbana: University of Illinois, 1992. Print. 
Grosz, Elizabeth A. Volatile Bodies: Toward a Corporeal Feminism. Bloomington: Indiana UP, 1994. Print.

Grosz, Elizabeth. Time Travels: Feminism, Nature, Power. Durham and London: Duke UP, 2005. Print.

Hekman, Susan J. The Material of Knowledge: Feminist Disclosures. Bloomington, IN: Indiana UP, 2010. Kindle.

Hemingway, Ernest, and Séan A. Hemingway. A Moveable Feast: The Restored Edition. New York, NY: Scribner, 2009. Kindle.

Herring, Phillip F. Djuna: The Life and Work of Djuna Barnes. New York: Penguin, 1996. Print.

Hoffman, Michael J., and Patrick D. Murphy. Essentials of the Theory of Fiction. Durham, NC: Duke UP, 2005. Print.

Jolly, Margaretta. "Autofiction." Encyclopedia of Life Writing: Autobiographical and Biographical Forms. London: Fitzroy Dearborn, 2001. 86-87. Print.

Kannenstine, Louis F. A Festschrift for Miss Barnes on Her 80th Birthday. Ed. Alex Gildzen. N.p.: Kent State U, 1972. Print.

Kaivola, Karen. All Contraries Confounded: The Lyrical Fiction of Virginia Woolf, Djuna Barnes, and Marguerite Duras. Iowa City: University of Iowa, 1991. Print.

Keeling, Bret L. "H.D. And The British Modernist Tradition: Kora And Ka. Mythopoesis And England's Great War." Approaches to Teaching H.D. 's Poetry and Prose. 114-119. New York, NY: Modern Language Association of America, 2011. Web.

Kowalewski-Wallace, Elizabeth. Encyclopedia of Feminist Literary Theory. New York: Garland, 1997. Print.

Linett, Maren Tova. Modernism, Feminism, and Jewishness. Cambridge: Cambridge UP, 2007. Kindle.

Linett, Maren Tova. The Cambridge Companion to Modernist Women Writers. Cambridge, UK: Cambridge UP, 2010. Print.

McAlmon, Robert, and Kay Boyle. Being Geniuses Together: 1920 - 1930. London: Joseph, 1970. Print.

O'Neal, Hank. "Life Is Painful, Nasty \& Short-- in My Case It Has Only Been Painful and Nasty": Djuna Barnes, 1978-1981 : An Informal Memoir. New York, N.Y:

Paragon House, 1990. Print. 
Plumb, Cheryl J. Fancy's Craft: Art and Identity in the Early Works of Djuna Barnes. Selinsgrove: Susquehanna UP, 1986. Print.

Ramanathan, Geetha. Locating Gender in Modernism: The Outsider Female. New York: Routledge, 2012. Print.

Rosner, Victoria. Modernism and the Architecture of Private Life. New York: Columbia UP, 2005. Print.

Russo, Mary J. The Female Grotesque: Risk, Excess, and Modernity. New York: Routledge, 1995. Print.

Scott, Bonnie Kime. Refiguring Modernism / the Women of 1928. Bloomington, IN: Indiana Univ. Pr., 1995. Print.

Seymour, Miranda. "So Much Genius, So Little Talent"" The New York Times. The New York Times, 25 Nov. 1995. <http://www.nytimes.com/1995/11/26/books/somuch-genius-so-little-talent.html?src=pm\&pagewanted $=1>$.

Shramko, Yaroslav, and Heinrich Wansing. "Truth Values." The Stanford Encyclopedia of Philosophy. Stanford University, 30 Mar. 2010. Web.

Sinclair, May. "The Novels of Dorothy Richardson" The Egoist, Vol. 5, No. 4, April 1908, 57. Web.

Smith, Sidonie, and Julia Watson. Reading Autobiography: A Guide for Interpreting Life Narratives. Minneapolis: U of Minnesota, 2010. Print.

Tarlo, Harriet. "'The New Comes Forward': Anglo-American Modernist Women Poets." Teaching Modernist Poetry. 58-76. Basingstoke, England: Palgrave Macmillan, 2010. eBook.

Warren, Diane. Djuna Barnes' Consuming Fictions. Aldershot, England: Ashgate, 2008. Print.

Wexler, Joyce Piell. Who Paid for Modernism: Art, Money, and the Fiction of Conrad, Joyce, and Lawrence. Fayetteville: University of Arkansas, 1997.

Woolf, Virginia, and Jeanne Schulkind. "A Sketch of the Past." Moments of Being. San Diego: Harcourt Brace Jovanovich, 1985. 61-159. 